\title{
o1. Kamus-ı Türkî’den günümüze Fransızca alıntı kelimelerde anlam değişmeleri
}

\section{Selcen KOCA ${ }^{1}$}

\begin{abstract}
APA: Koca, S. (2021). Kamus-ı Türkî'den günümüze Fransızca alıntı kelimelerde anlam değişmeleri. RumeliDE Dil ve Edebiyat Araştırmaları Dergisi, (22), 1-27. DOI: 10.29000/rumelide.885408.
\end{abstract}

$\ddot{O} \mathbf{z}$

Kültürel ve dolayısıyla dilbilimsel temasın doğal sonuçlarından biri olan sözcüksel ödünçleme, kaynak konumundaki verici dilden alıcı dilin söz varlı̆̆ına yapılan kelime aktarımıdır. Sözcüksel ödünçlemeyi teşvik eden temel etkenler, sözcüksel boşluğu doldurma ihtiyacı ve prestij kazanma isteğidir. Yabancı bir kaynak dilden ödünçlenen kelimeler, az veya çok; fonolojik, ortografik, morfolojik ve anlamsal açıdan alıcı dilin sistemine uyum sağlayacak şekilde değiştirilerek kullanılırlar. Bu çalışmanın konusu olarak seçilen alıntı kelimelerdeki anlam değişmeleri, farklı şekillerde ve aşamalarda gerçekleşebilmektedir. Alıntı kelimeler, alıcı dile ilk kez tanıtıldığında kaynak dildekinden farklı bir anlam gösterebileceği gibi dile uyarlandıktan sonra süreç içerisinde de anlam değişimine uğrayabilir. Özellikle Tanzimat dönemiyle artan ve 20. yüzyılın ortalarına kadar etkisini sürdüren Türk-Fransız teması, Türkçeye Fransızca kelimelerin ödünçlenmesi sonucunu doğurmuştur. Türkçede yeni kavram, madde ve eşyaları karşılayan kelimelere duyulan ihtiyaç Fransızcadan yapılan sözcüksel ödünçlemelerin başlıca nedenidir. Bu çalışmada, Tanzimat dönemi aydınlarından Şemseddin Sami tarafından hazırlanan Kamus-ı Türkî'deki Fransızca alıntı kelimeler tespit edilerek bu kelimelerin günümüzde geçirdiği anlam değişmeleri analiz edilmiştir. Fransızca alıntı kelimelerdeki anlam değişmeleri, konuyla ilgili tipolojilere göre anlam genişlemesi, anlam daralması, anlam aktarımı (metafor, metonimi, sinekdoka) alt başlıkları altında incelenmiş; anlam olayları dışında galatlar yoluyla oluşan anlam değişmelerine de yer verilmiştir. Böylece, hem 19. yüzyıldan günümüze Fransızca alıntı kelimelerdeki anlam değişmeleri belirlenmiş hem de bu kelimelerin kaynak dilden farklı olarak Türkçede kazandıkları özgün anlamlar ortaya koyulmuştur.

Anahtar kelimeler: Alıntı kelime, anlam değişmeleri, Kamus-ı Türkî, anlam genişlemesi, anlam daralması, anlam aktarımı

\section{Semantic changes of French loanwords from Kamus-ı Türkî to contemporary Turkish}

\begin{abstract}
Lexical borrowing, one of the natural consequences of cultural and hence linguistic contact, is the transfer of words from the source or donor language to the vocabulary of the recipient langauage. The main motivation of lexical borrowing are the need to fill the lexical gap and desire to gain prestige. Words borrowed from a foreing source language undergo, more or less; phonological, orthographic, morphological and semantic changes to adapt to the system of the recipient language. Semantic changes in the loanwords selected as the subject of this study can occur in different ways and stages. Semantic changes can occur when the loanwords are introduced to the recipient
\end{abstract}

Arş. Gör. Dr., Hitit Üniversitesi, Fen Edebiyat Fakültesi, Türk Dili ve Edebiyatı Bölümü (Çorum, Türkiye), selcenkoca@hitit.edu.tr, ORCID ID: oooo-0oo3-4195-9157 [Araştırma makalesi, Makale kayıt tarihi: 24.11.2020-kabul tarihi: 20.03.2021; DOI: 10.29000/rumelide.885408]

Adres

RumeliDE Dil ve Edebiyat Araşttrmaları Dergisi Osmanağa Mahallesi, Mürver Çiçeği Sokak, No:14/8

Kadıköy - İSTANBUL / TÜRKIYE 34714 e-posta: editor@rumelide.com

tel: +90 $5057958124,+902167730616$

\section{Address}

RumeliDE Journal of Language and Literature Studies

Osmană̆a Mahallesi, Mürver Çiçeği Sokak, No:14/8

Kadıköy - ISTANBUL / TURKEY 34714

e-mail: editor@rumelide.com,

phone: +90 $5057958124,+902167730616$ 


\begin{abstract}
language for the first time or after the loanword is adapted to the language. Turkish-French contact, which increased especially with the Tanzimat period and continued its influence until the middle of the 20th century, resulted in the borrowing of French words into Turkish. The need for words corresponding to new concepts, entities and goods in Turkish is the main reason for lexical borrowings from French. In this study, French loanwords in Kamus-ı Türkî, prepared by Şemseddin Sami, one of the Tanzimat period intellectuals, were determined and the semantic changes in French loanwords have been examined under the sub-heading of semantic widening, semantic narrowing, semantic shift (metaphor, metonymy, synecdoche) according to the relevant typologies, and besides the meaning event, the semantic changes occurring through the galat (language mistakes) are also included. Thus, both the semantic changes in the French loanwords from the 19th century to the present were determined, and the original meanings that these words acquired in Turkish, different from the source langauage, were revealed.
\end{abstract}

Keywords: Loanword, semantic change, Kamus-ı Türkî, semantic widening, semantic narrowing, semantic shift

\title{
Giriş
}

Sosyal bir olgu olarak dil, devamlı bir gelişim ve değişim gösterir. Dilde meydana gelen bu değişim ve gelişim, dil içi ve dil dışı olmak üzere iki kaynaktan beslenir (Barber 1964: 1). Çeşitli etkenler sonucu ortaya çıkan dil içi değişimler, dilin kendi sistemi içerisinde ve kendine özgü kurallarıyla açıklanabilir. Dilin başka dillerle teması ve etkileşimi neticesinde meydana gelen dil dışı değişimler ise, hem dilin kendi yapısının hem de temasta bulunduğu dilin özelliklerini barındırır. Dil dışı değişimlere kaynaklık eden dil teması ve etkileşimi, dilbilimsel unsurların ödünçlenmesiyle sonuçlanır. Diller arasında hemen hemen her tür dil unsuru ödünçlenebilmekle birlikte, en yaygın ödünçleme, kelime alışverişidir.

Yabancı bir dil ve kültürden ödünçlenen kelimeler, dâhil edildikleri dilin kültürel ve dilbilimsel bağlamına uygun bir şekilde değiştirilerek alıcı dile uyarlanır. Buna göre alıntı kelimelerin fonolojik, morfolojik ve anlamsal özellikleri alıcı dilin kendi sistemi içinde yerlileştirilir. $\mathrm{Bu}$ uyarlama, ödünçlemenin ilk defa gerçekleştiği zamanda olabildiği gibi süreç içerisinde de şekillenebilir. Alıntı kelimenin alıcı dile çeşitli açılardan uyumlu hâle getirilmesinde sadece dilbilimsel etkenler belirleyici olmaz. Dilin içinde geliştiği kültürel, sosyal, siyasi, ekonomik yapı gibi pek çok farklı unsur; alıntı kelimelerin uyarlanma sürecini doğrudan veya dolaylı bir şekilde etkiler. Bu nedenle alıntı kelimelerin farklı açlardan incelenmesi, sadece dilbilimsel açıdan dilin geçirdiği değişim ve gelişime ışık tutmaz; aynı zamanda tarihî olay ve olgulara da tanıklık edebilir (Adelaar 1994: 50); sosyal yapının ve kültürü şekillendiren düşünce sisteminin çözümlenmesine olanak sağlar.

Türk dili, ilk dönemlerinden itibaren içinde bulunduğu coğrafyaya ve temasta bulunduğu kültür dairelerine göre pek çok yabancı dille etkileşim içerisinde bulunmuştur. Yüzyıllardır oldukça dinamik temas alanlarında varlığını sürdüren Türk dili; Çince, Moğolca, Soğdca, Tunguzca, Farsça, Arapça ve nispeten son dönemlerde Fransızca, İtalyanca, İngilizce gibi çoğunlukla genetik ve tipolojik açıdan farklı diller ve dil aileleriyle etkileşim göstermiştir (Johanson vd. 2020: 551-552).

$\mathrm{Bu}$ çalışmanın konusu olarak belirlenen Türkçe-Fransızca dil temasını ve bu temasın sonuçlarını değerlendirebilmek için Türk-Fransız ilişkilerine kısaca değinmek gerekir. Siyasi ve ticari münasebetler bağlamında başlayan Türk-Fransız ilişkileri, Osmanlı devletinde 18. yüzyılda başlayan,

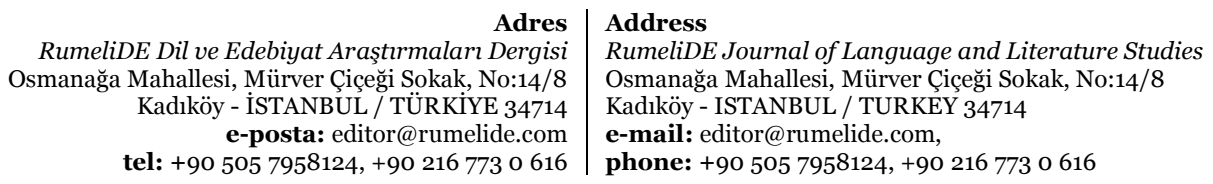


Tanzimat fermanıyla (1839) hız kazanan yenileşme ve dolayısıyla Batılılaşma cereyanının etkisiyle sosyal ve kültürel alanlarda da etkisini göstermiştir. Özellikle 18. ve 19. yüzyıllarda Fransız dili ve kültürünün diplomasi, bilim, teknoloji, sanat, edebiyat ve felsefe gibi pek çok alanda dünya genelinde öncü konumda yer alması, Fransızcanın belirtilen dönemde 'ortak dil' (lingua franca) olarak yaygınlaşmasına neden olur (Uysal 2014: 48). Osmanlı devletinde yenileşme ve batıllış̧ma faaliyetleri, Fransa modeli kaynak alınarak şekillendirilir. Başka bir deyişle, Batılılaşma ve Avrupalılaşmaya zemin hazırlayacak her tür kavram, bu dönemde Fransız etkisi ve Fransa kanalıyla Osmanlı toplumuna entegre edilir. ${ }^{2} \mathrm{Bu}$ durumun doğal bir sonucu olarak da Türkçede bulunmayan yeni kavramlar ve nesnelerin karşılıkları Fransızcadan ödünçlenmeye başlanır.

Yenileşme çabaları sonucu yönünü Batıya, özellikle de Fransa'ya, çeviren Osmanlı devletinde, Fransız kültürünü ve toplum yapısını daha iyi tanımak ve değerlendirebilmek için çeşitli faaliyetlerde bulunulmuştur. Devlet kanalıyla gönderilen elçiler ve devlet adamları ile şahsi gayretleriyle Fransa'ya giden Türk aydınları; Fransız bilim, kültür ve sosyal hayatının Osmanlı toplumuna tanıtılmasında başlıca rol üstlenmişlerdir. Fransızca eğitim veren kurumların sayısındaki artış; roman, hikâye, tiyatro gibi yeni edebî türlerin; gazete ve dergi gibi yeni yayın organlarının Batılı anlayış etkisi altında ortaya çıkışı ve gelişmesi, Fransızcadan yapılan tercüme faaliyetlerinin hız ve yaygınlık kazanması ve Fransızcanın yabancı dil olarak popülerliğinin artması Türkçede çeşitli Fransızca kelimelerin kullanımına ve zamanla dile yerleşmesine zemin hazırlamıştır (Uysal 2014: 48-51; Magrelo 2011: 8).

Biraz yukarıda bahsedilen sosyal ve kültürel hayattaki değişim ve özellikle 20. yüzyılda bilim ve teknolojide yaşanan gelişmeler neticesinde, Tanzimat döneminde başlayan Fransız dili ve kültürünün etkisi, II. Dünya Savaşı sonrasına (20. yüzyıl ortalarına) kadar artarak devam etmiştir. Bu etkileşim; çeşitli bilim ve sanat dallarıyla ilgili terimlerin, teknolojik buluşları ve eşyaları karşılayan ve hukuk, ticaret, ekonomi, tekstil vb. çeşitli alanlardan kelimelerin Fransızcadan ödünçlenmesi sonucunu doğurmuştur. Bununla birlikte, sadece köken bakımından Fransızca olan kelimeler değil, aynı zamanda Batı kaynaklı başka dillere ait kelimeler de belirtilen dönemde Fransızca yoluyla Türkçeye ödünçlenmiştir. Günümüzde Batı dilleri arasında Türkçenin en fazla kelime ödünçlediği dil Fransızcadır3 (Durmuş 2004: 8).

$\mathrm{Bu}$ çalışmanın konusu, Tanzimat dönemi sözlüklerinden olan Kamus-ı Türkî'deki Fransızca alıntı kelimelerin günümüzde gösterdiği anlam değişmeleridir. Çalışmanın ana malzemesi olarak belirlenen Kamus-ı Türkî'de yer alan Fransızca alıntı kelimeleri tespit etmede Paşa Yavuzarslan tarafından (2019) hazırlanan, eserin Latin harflerine aktarılmış yayını esas alınmıştır. Kamus-ı Türkî'de yer alan Fransızca alıntı kelimeler, kullanım ve anlam özellikleriyle belirlendikten sonra, kelimelerin bahsi geçen özelliklerinin güncel Türkçedeki görünümlerini tespit edip bir karşılaştırmada bulunmak için Türk Dil Kurumu'nun çevrimiçi Güncel Türkçe Sözlük'ü kaynak olarak kullanılmıştır. Türkçedeki Fransızca alıntı kelimelerin anlam ve kullanım özelliklerini daha iyi değerlendirebilmek için kelimelerin kaynak dil olan Fransızcadaki anlam ve kullanımları da incelenmiştir. Bunun için hem Kamus-ı Türkî̀yle çağdaş Fransızca sözlüklerden (Bellows' French Dictionary, 3. baskı, 1916; Şemseddin Sami tarafından hazırlanan Resimli Kâmûs-1 Fransevî, 1901-1905) hem de güncel Fransızca sözlüklerden (Tahsin Saraç, Büyük Fransızca-Türkçe Sözlük, 1985) yararlanılmıştır. Böylece diyakronik (art zamanlı) bir anlam analizi şeklinde sunulan çalışmada, Fransızca alıntı kelimelerdeki

Tanzimat döneminde Frenk (Fransı) kelimesinin "Avrupalı" anlamında kullanılması, bu durumun en önemli göstergesidir. Başka bir deyişle, bu dönemde Avrupa kavramının en önemli temsilcisi Fransa'dır.

Oğuzhan Durmuş (2004), Türk Dil Kurumu tarafından hazırlanan Türkçe Sözlük'ün 9. baskısından (1998) hareketle Türkçedeki alıntı kelimelerle ilgili sayısal veriler sunmuştur. Söz konusu çalışmaya göre Türkçede, 4645 Fransızca alıntı kelime bulunmakta ve böylece Fransızca Batı dilleri arasında en çok kelime ödünçlenen dil olarak belirlenmektedir.

Adres $\mid$ Address

RumeliDE Dil ve Edebiyat Araşttrmaları Dergisi $\quad$ RumeliDE Journal of Language and Literature Studies Osmanağa Mahallesi, Mürver Çiçeği Sokak, No:14/8 Osmanağa Mahallesi, Mürver Çiçeği Sokak, No:14/8

Kadıköy - ISTANBUL / TÜRKIYE 34714 Kadıköy - ISTANBUL / TURKEY 34714 e-posta: editor@rumelide.com

e-mail: editor@rumelide.com

tel: +90 505 7958124, +90 216773 o 616 phone: +90 505 7958124, +90 2167730616 
anlam değişmelerinde kaynak dil Fransızcanın etkisi ve özgün anlamlandırma süreçleri ortaya koyulmaktadır.

\section{1. Ödünçleme ve alıntı kelime}

Ödünçleme (İng. borrowings), dilbilimsel unsurun bir dilden başka bir dile aktarılması olarak tanımlanabilir. En genel ve yaygın şekliyle ödünçleme, bir dile başka bir dilden yapılan tüm aktarma ve kopyalama süreçlerini karşllayan bir terimdir (Haspelmath 2009: 36). Ödünçleme, daha önce başka bir dilde bulunan kalıpların dilde yeniden üretilme teşebbüsüdür ve bir durumu değil, diller arası temastan doğan süreci belirtir (Haugen 1950: 212-213). Ödünçleme sürecinin en yaygın sonuçlarından biri, alıntı kelimelerdir. Bu bağlamda alıntı kelime (İng. loanword) veya sözcüksel ödünçleme ise, kaynak konumundaki verici dilden (İng. donor language) ödünçleme sonucu alıcı dilin (İng. recipient language) söz varlığına aktarılan kelimedir (Haspelmath 2009: 36).

Yabancı kelime olarak tanımlanabilecek sözcüksel bir birimin alıntı kelime hâline gelebilmesi için alıcı dil konuşurlarının büyük bir kısmı tarafından benimsenmesi ve sıklıkla kullanılması gerekir. Bununla birlikte, alıcı dile entegre edilen her yabancı kelime nihayetinde alıntı kelime olarak dilin söz varlığına dâhil edilmektedir (Hoffmann 2011: 137). Yabancı kelimeler, az veya çok, alıcı dilin sistemine uymayan fonolojik, ortografik, morfolojik ve söz dizimsel özelliklere sahiptir (Haspelmath 2009: 42). Bu nedenle ödünçleme sürecinde yabancı kelimeler, alıcı dilin sistemine uyum sağlayacak şekilde değiştirilerek yerlileştirilir. Bununla birlikte, yabancı bir kelimenin alıcı dile uyarlanma derecesi, alıntı kelimenin eskiliğine, alıcı dil konuşurlarının kaynak dili bilme seviyelerine ve kaynak dile karşı tutumuna bağlı olarak değişir (Haspelmath 2009: 42). Örneğin nispeten yeni alıntı kelimeler, kaynak dildekine yakın bir telaffuzla ifade edilirken kelimenin kullanımının yaygınlaşmasıyla, süreç içerisinde alıcı dilin fonolojik yapısına uyum gösterir. Uzun süre, sıklıkla kullanılan alıntı kelimeler, dilin ana kelimelerine giderek daha çok benzer. Pek çok açıdan yerlileştirilen bu tür alıntı kelimeleri, dilin ana kelimelerinden ayırmak neredeyse imkânsızdır. Bununla birlikte, kaynak dille ilgili bilginin ve temasın artması, sadece kelimelerin değil, morfolojik unsurların da ödünçlenmesine neden olur.

Alıntı kelimenin dâhil olduğu yeni dilbilimsel bağlama uyması ve yeni dilbilimsel kurallara bağlanması için alıcı dilin sistemine göre düzenlenecek değişikliklere uğraması gerekir. Yabancı unsurların alıcı dile uyarlanma süreci çok yönlü, aşamalı, uzun bir süreçtir; ancak bu değişim, doğal bir şekilde gerçekleşir ve dilin canlı yapısının beklenen bir sonucudur (Herman 2008: 81). Uyarlanma ve yerlileştirilme sürecinde alıntı kelime fonolojik, morfolojik, anlam bilimsel ve dil bilgisel bir dizi değişiklik gösterebilir. Bununla birlikte, alıntı kelimenin telaffuz, yazım, morfoloji ve söz dizimi açısından uyarlanmasını içeren biçimsel; konuşurların sözcüksel birime karşı tutumlarını ifade eden psikolojik; alıntı kelimeye genel olarak 'iyi' (resmi) veya 'kötü' (yarı resmi) derecelerinin verildiği sosyal; alıntı kelimenin anlam bilimsel açıdan uyarlanması ve dilin diğer kelimeleriyle ilişkisinin belirlenmesini içeren sözcüksel uyarlama süreçlerinden de bahsedilebilir (Hoffmann 2011: 136; Kowner\&Daliot-Bul 2008).

Alıntı kelimelerin uyarlanma ve yerlileştirilme süreci genel olarak dört aşamaya ayrılır (Hoffmann 2011: 136; Görlach 2003: 25-26; Breiter 1997: 93-95):

1. Fonolojik ve grafiksel entegrasyon, uyarlama sürecinin ilk aşamasıdır. Alıntı kelime, genellikle kaynak dildeki şekliyle yazılır; alıcı dildeki kelimelere benzemez. Bu aşamadaki alıntı kelimelerin kullanımı sinırlıdır.

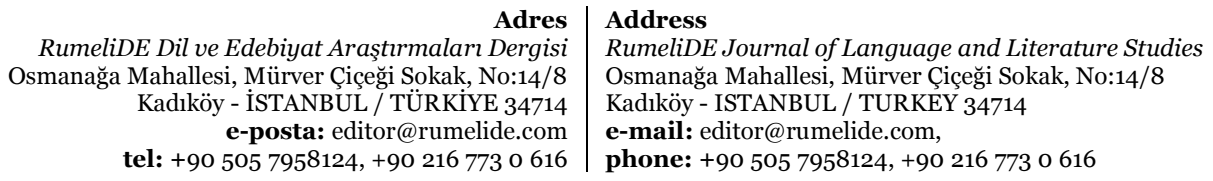


2. Morfolojik entegrasyon, alıntı kelimelerin dile dâhil edildiği aşamadır. Alıntı kelimelerin yazımı ve morfolojik özellikleri kaynak dildekine yakındır. Fonolojik ve dil bilgisel açıdan alıcı dile uyarlanma süreci başlamıştır; alıntı kelimelerin telaffuzları kaynak dildekine yakın olsa da yazımları alıcı dile uyarlanmıştır.

3. Türetimsel entegrasyon, alıntı kelimenin konuşurların çoğu tarafından kabul edildiği aşamadır. Alıntı kelimeler, alıcı dilin imkânları dâhilinde çekimlenebilir. Bununla birlikte, alıntı kelime yerel bir kelime olarak görülmez.

4. Anlamsal entegrasyon, alıntı kelimelerin alıcı dile ait yerel unsurlar olarak kabul edildiği, kelimenin her yönüyle yerlileştirildiği uyarlama sürecinin son aşamasıdır. Alıntı kelime, günlük konuşma dilinde yaygın bir şekilde kullanılır, çekimlenebilir, kelime türetme sürecinde işletilebilir.

Alıntı kelimeler, alıcı dilde karşıladıkları kavramlar bakımından kültürel ödünçlemeler (İng. cultural borrowings) ve temel ödünçlemeler (İng. core borrowings) olmak üzere ikiye ayrilır (Myers-Scotton 2002: 41). İhtiyaçtan kaynaklanan ödünçlemeler olarak da adlandırılabilecek kültürel ödünçlemeler, alıcı dilde karşılı̆̆ı olmayan yeni nesneler veya yeni kavramlar için ödünçlenen kelimelerdir ve genellikle etkili grupların bu tür kelimeleri kullanmaya başlamasıyla aniden ortaya çıkar. Temel ödünçlemeler ise, alıcı dilde hâlihazırda bulunan kelimeleri az veya çok tekrarlayan kelimelerdir (Myers-Scotton 2002: 239). Bu tür ödünçlemeleri destekleyen motivasyon, genellikle kaynak dilin prestijli konumudur.

Ödünçleme sürecini teşvik eden pek çok farklı neden vardır. Biraz yukarıda ifade ettiğimiz yeni nesne ve kavramları ifade etmek için ihtiyaçtan kaynaklanan kültürel ödünçlemeler, sözcüksel ödünçlemelerin en önemli ve en yaygın nedenlerinden biridir. Trask'a göre (1994: 9), alıcı dilde yeni bir kavramı karşılayacak kelime bulunmadığı zaman sözcüksel ödünçlemeler kaçınılmazdır. Her ne kadar her dil yeni nesne ve kavramları karşılayacak yeni kelimeler oluşturmak için yeterli yaratıcı kaynaklara sahip olsa da, bu tür ödünçlemeler, dilde karşllğ̆ olmayan yeni kavramları ifade etmenin en kolay ve pratik yoludur (Katamba 2005: 138-139; Danesi\&Rocci 2009: 161). İhtiyaç olmadığı hâlde, alıcı dilde karşılığı olan kelimelerin ödünçlenmesinin altında yatan sebeplerin belirlenmesi ise oldukça zordur. Bu tür ödünçlemelerin en önemli sebeplerinden biri, kaynak dilin alıcı dil karşısında daha prestijli bir konuma sahip olmasıdır. Bununla birlikte, daha eğitimli görünme ve yabancı dil bilgisini ispat etme çabası, daha modern ve modaya uygun davranış sergileme (Rebuck 2002: 57-58), dilde yeni bir ifade tarzı oluşturma, dil ekonomisi için kelimeleri basitleştirme (Apenteng\&Amfo 2014: 238), çok dilli bir ortamda yaşama (Bator 2010: 41), dildeki kelimelerin eş anlamlılarını kullanarak üslubu zenginleştirme isteği (Anam\&Nirmala 2019: 88-89); dildeki kelimelerin olumsuz çağrışımlarının bulunması, tabu kelimeleri ifade etme ihtiyacı ve eş seslilikten kaçınma (Haspelmath 2009: 50) ${ }^{4}$ gibi anlayışlar; alıcı dil kullanıcılarının ihtiyaç dışında başka dillerden kelime ödünçlemesinin nedenleri olarak sayllabilir. Buraya kadar ifade ettiğimiz ödünçlemelere sebep olan etkenler dilbilimseldir. Bununla birlikte, dilbilimsel etkenler dışında değerlendirilebilecek siyasi, kültürel, dinî veya ekonomik ilişkiler de ödünçlemelerin nedenini oluşturabilir (Bator 2010: 41).

\footnotetext{
$4 \quad$ Ses değişikliği sonucu dildeki iki farklı kelime eş sesli hâle gelirse iki kelimenin anlam bakımından karıştırılmasını önlemek için sözcüksel ödünçlemeye başvurulabilir.

Adres $\mid$ Address

RumeliDE Dil ve Edebiyat Araşttrmaları Dergisi $\quad$ RumeliDE Journal of Language and Literature Studies Osmanağa Mahallesi, Mürver Çiçeği Sokak, No:14/8 Osmanağa Mahallesi, Mürver Çiçeği Sokak, No:14/8 Kadıköy - İSTANBUL / TÜRKIYE 34714 Kadıköy - ISTANBUL / TURKEY 34714 e-posta: editor@rumelide.com tel: $+905057958124,+902167730616$ e-mail: editor@rumelide.com

phone: +90 505 7958124, +90 2167730616
} 


\section{2. Ödünçlemelerde anlam değişmeleri}

Kelimelerin anlamlarında görülen değişikliklerle ilgili bir kavram olan anlam değişmesi, kelimelerin zaman içinde değişen kullanım özellikleridir. Sözcüksel bir öge, sahip olduğu, mevcut olanlara ek veya farklı anlamlar geliştirebilir. Başka bir deyişle, sözcüksel bir ögenin karşıladı̆̆ı mevcut anlamlar değişebilir ve eski anlamlar geçersiz hâle gelerek bunların yerini yeni anlamlar alabilir veya yeni anlamlar yerleşik anlamların uzantıları olarak gelişerek yeni ve eski anlamlar bir arada var olup çok anlamlılığa yol açabilir (Murphy\&Koskela 2010: 147). Bazı durumlarda, çok anlamlı bir kelimenin anlamlarındaki belirginlikte bir değişim meydana gelebilir; böylece daha önce temel veya belirgin olarak kabul edilen bir anlam, yerini daha az öne çıkan başka bir anlama bırakır.

Genellikle öngörülemeyen ve kaçınılmaz olan anlam değişmeleri, dilin kendi söz varlığına ait kelimelerde görülebildiği gibi başka dillerden ödünçlenen kelimelerde de gerçekleşebilir (Bader 1990: 35). Alıntı kelimelerin çoğu, ödünçleme sürecinde bazı anlamsal değişimlere uğramaktadır (Weinreich, 1963: 53-55). Kaynak dildekiyle tamamen aynı anlamı veya kullanım özelliklerini koruyan alıntı kelime neredeyse yoktur. Bununla birlikte, anlamdaki değişimin boyutu, küçük bir nüanstan tamamen farklı bir anlam kazanmaya kadar çeşitlenebilir.

Ödünçlenen herhangi bir kelime, dilbilimsel olduğu kadar kültürel sınırları da aşar ve bu durum ise anlamsal çeşitliliğin kapılarını açar (Hall-Leww, 2002: 9). Başka bir deyişle, alıcı dilin içerisinde şekillendiği tarihî, kültürel ve sosyal yapı, alıntı kelimelerin bağlamsal kullanımını etkiler. Bu nedenle, alıntı kelimelerin kaynak dilden farklı anlamlara ve işlevlere sahip olması beklenen doğal bir süreçtir.

Alıntı kelimelerdeki anlam değişmeleri, farklı şekillerde ve aşamalarda gerçekleşebilir. Alıcı dile ilk kez tanıtıldığında alıntı kelimeye orijinal anlamından farklı bir anlam yüklenebilir. Daha yaygın bir şekilde ise, alıntı kelime uyarlandıktan sonra alıcı dilin kullanım özelliklerine göre anlam değişimi gösterir. Genellikle alıntı kelimenin kaynak dilde sahip olduğu anlamlardan sadece biri ödünçlenir. Bununla birlikte dil temasının devam etmesi sonucu, önce bir anlamıyla ödünçlenen kelimenin diğer anlamlarının daha sonra dile entegre edilmesi de söz konusudur. Bazı alıntı kelimeler ise, doğrudan kaynak dilden değil, başka diller aracilığıyla ödünçlenir; bu tür durumlarda anlamsal tercihler de ödünçlemenin yapıldığı dile bağlı olarak değişebilmektedir.

Toplum hayatında meydana gelen değişimler, sürekli olarak yeni kelime dağarcığı gerektirir. Kelimeler, genellikle, değişen toplumun ihtiyaçlarına yanıt olarak uyarlanmış anlamlar alır. Biraz yukarıda da ifade edildiği gibi, alıntı kelimeler özellikle hem dile girerken hem de zamanla değişikliğe açıktır. Bu durumun nedenlerinden biri, alıntı kelimenin kaynak dildeki anlamının veya kullanım özelliklerinin tam olarak anlaşılmamasıdır. Ayrıca, alıntı kelimelerin orijinal anlamlarını korumak için güçlü bir kültürel motivasyon yoktur. Alıntı kelimelerin biçim ve anlamındaki esneklik, bunların alıcı dilin yapısına, mevcut eğilimlere ve ihtiyaçlara kolayca uyum sağlamasına olanak tanır (Kay 1995: 72).

Alıntı kelimelerle alıcı dilin söz varlığı arasında karşılıklı bir etkileşim vardır. Söz varlığı, kendi içerisinde bir ilişkiler ağı oluşturur. Belirli bir içerik alanına sahip olan kelimelerin anlamları, diğer kelimelerle aralarındaki yakınlık ve zıtlık ilişkisi içerinde incelenebilir (Kittay\&Lehrer 1992: 3-4). Buna göre anlamsal alana alıntı kelime gibi yeni bir ögenin eklenmesi, hem o alandaki diğer kelimelerin anlamlarını hem de alıntı kelimenin anlamını etkiler.

\begin{tabular}{|c|c|}
\hline & \\
\hline debiyat & Studie \\
\hline $\mathrm{Mah}$ & Mahallesi, Mürver Çiçeği Sokak, No:14/8 \\
\hline Kadıköy - İ & STANBUL / TURKEY 34714 \\
\hline $\begin{array}{r}\text { e-posta: editor@rumelide.com } \\
\text { tel: }+905057958124,+902167730616\end{array}$ & $\begin{array}{l}\text { e-mail: editor@rumelide.com, } \\
\text { phone: +90 505 7958124, +90 } 2167730616\end{array}$ \\
\hline
\end{tabular}


Kaynak dil ile alıcı dil arasındaki anlamsal değişimi tespit etmek, bu değişikliklerin neden ve nasıl gerçekleştiğini tam olarak belirlemek kadar zor değildir (Hall-Lew 2002: 8). Başka bir deyişle, alıntı kelimelerdeki anlam değişmelerinin neden kaynaklandığı, sürecin hangi yönde ve ne tür etkilerle şekillendiği kesin bir şekilde çözümlenemez. Hock (1980: 283; 285) anlam değişmelerinin oldukça rastgele, düzensiz bir şekilde geliştiği ve tahmin edilmesinin son derece zor olduğu görüşündedir. Bununla birlikte, toplum ve kültür hayatındaki radikal değişikliklerin ortaya çıkardığı bazı anlam değişmelerinde belirli bir sistematikliğin görülebileceğini kabul eder. Örneğin 20. yüzyılın başında 'at' ve 'at arabası'nın yerini 'otomobil'in alması 'araba' ve 'araba kullanma' kelimelerinin büyük bir anlam değişimine uğramasına neden oldu. Söz konusu kelimelerin geçirdiği anlam değişmesi, teknolojik gelişmelerle kolayca tahmin edilebilir. Bununla birlikte, anlam değişmeleri çoğu durumda öngörülemez olsa da tamamen kaotik değildir (Pyles\&Algeo 1982: 242).

Anlam değişmeleri, oluşumları ve kullanımları açısından çeşitlilik gösterir. Bu bağlamda anlam değişmelerinin türlerini ve tipolojilerini belirlemeye yönelik farklı anlayışlardan bahsedilebilir. Anlam değişmelerinin tipolojisi üzerine ilk sistematik çalışmalar 20. yüzyılda başlamıştır. Stern (1931: 165169); anlam değişmelerini yerine koyma, analoji, kısaltma, adlandırma, düzenli aktarma, becayiş, eş değer olma şeklinde yedi başlık altında inceler. Anlam değişmelerini daha ayrıntılı bir sınıflamaya tabi tutan Bloomfield ise (1933: 426-427); anlam daralması, anlam genişlemesi, metafor, metonimi, sinekdoka, mübalağa, ayrıksayış, anlam kötüleşmesi ve anlam iyileşmesi olmak üzere dokuz farklı anlam değişmesinden bahseder. Ullmann (1957/1967: 211-235), anlam değişmelerinin türü ve sonuçlarını birbirinden ayırır. Buna göre metafor, metonimi, halk etimolojisi, kısaltma anlam değişmelerinin türü olarak belirlenirken anlam genişlemesi, anlam daralması, anlam iyileşmesi ve anlam kötüleşmesi anlam değişmelerinin sonucudur. Anlam değişmelerinin tipolojisini belirlemeye yönelik en son ve en ayrıntılı çalışma Blank'a aittir (1999: 70-82). Anlam değişmelerini metafor, metonimi, sinekdoka, özelleştirme, genelleştirme, eş altanlamlılık aktarımı, tersinleme, otomatik zıt anlam, otomatik tersinleme, kısaltma ve halk etimolojisi şeklinde sinıflandıran Blank (1999), nesnel bir şekilde belirlenemeyeceği düşüncesiyle anlam iyileşmesini ve anlam kötüleşmesini tipolojisine dâhil etmez.

\section{Kamus-ı Türkî ve Fransızca alıntı kelimeler}

19. yüzyılın çok yönlü aydınlarından biri olan Şemsettin Samî (1850-1904), roman ve tiyatro gibi edebî türlerdeki telif ve tercüme eserleri, öğretici mahiyetteki ansiklopedik çalışmaları ve çeşitli konularda kaleme aldığı gazete ve dergi yazılarının yanı sıra şöhretini hazırladığı sözlüklerle kazanmıştır. Şemseddin Samî'nin Fransızcadan Türkçeye ve Türkçeden Fransızcaya olmak üzere iki cilt halinde hazırlanan Kâmûs-ı Fransevî, Arapçadan Türkçeye tamamlanmamış Kâmûs-ı Arabî ve döneminin Türkçe söz varlığını içeren Kâmûs-ı Türkî olmak üzere üç farklı sözlüğü bulunmaktadır (Yavuzarslan 2004: 195). Bahsi geçen sözlükler arasında Kâmûs-ı Türkî, içeriği ve hazırlanış şekliyle hem yayımlandı̆̆ı dönemde güncel hem de günümüzde tarihî bir öneme sahiptir.

Kâmûs-ı Türkî (1901), özellikle zengin içeriğiyle Osmanlı dönemi Türk sözlükçülüğünde önemli bir köşe taşıdır (Demiray 1981: 24; Yavuzarslan 2004: 200). Tanzimat dönemine kadar genellikle sadece Arapça ve Farsça kelimeleri ihtiva eden Osmanlı dönemi Türk sözlükçülük anlayışı, bu dönemden sonra Batı sözlükçülük modeli çerçevesinde tekrar şekillenmiş; Osmanlı Türkçesinin temelini oluşturan Türkçe kelimeler de sözlüklere dâhil edilmeye başlamıştır (Yavuzarslan 2004: 199). Osmanlı dönemi Türk sözlükçülüğündeki bu çabanın ilk örnekleri arasında yer alan Kamus-ı Türkî, hem güncel hem de kullanımdan düşmüş, eski Türkçe söz varlı̆̆ını büyük oranda içerir. Kamus-ı Türkî'de Arapça,

\footnotetext{
\begin{tabular}{r|l} 
Adres & Address \\
RumeliDE Dil ve Edebiyat Araşttrmalar Dergisi & RumeliDE Journal of Language and Literature Studies
\end{tabular} Osmanağa Mahallesi, Mürver Çiçeği Sokak, No:14/8 $\quad$ Osmanağa Mahallesi, Mürver Çiçeği Sokak, No:14/8 Kadıköy - İSTANBUL / TÜRKIYE 34714 Kadıköy - ISTANBUL / TURKEY 34714 e-posta: editor@rumelide.com e-mail: editor@rumelide.com, tel: +90 505 7958124, +90 2167730616 phone: +90 505 7958124, +90 2167730616
} 
Farsça alıntı kelimelerin yanı sıra dönemin söz varlığındaki Yunanca, Latince, İtalyanca, Fransızca gibi Batı dillerinden ödünçlenmiş kelimelere de kaynakları belirtilerek yer verilmiştir.

Yaklaşık 30.00o kelimelik söz varlığını içeren Kamus-ı Türkî'de (Çiçek 2009: 188), çeşitli eklerle oluşturulan yeni kelimeler ve birleşik kelimeler dışında, madde başı olarak 241 Fransızca alıntı kelime bulunmaktadır. Bununla birlikte, bazı Türkçe (abone-abonelik, avukat-avukatlık, entrika-entrikacı, balon-baloncu-balonculuk) ve Arapça (elektrik-elektrikî, elektrik-elektrikiyyet, kumandankumandanî) ekler kullanılarak Fransızca alıntı kelimelerin işletilmesiyle ve alıntı kelimelere Türkçe söz varlığında bulunan çeşitli kelimelerin eklenmesiyle tamlama ve birleşik kelime yapısında (şifre-şifre kalemi, salon-salon adamı, vapur-kara vapuru, bütçe-bütçe açığı-bütçe açığını kapamak) yeni sözcük birimleri de türetilmiştir. Kamus-ı Türkî'deki Fransızca alıntı kelimeler, kullanım alanları bakımından çeşitlilik gösterir. Edebiyat ve sanat (aktris, aktör, roman, pandomim, piyano, mandolin, nota), askerî ve idari unvanlar (amiral, prens, arşidük, general, jandarma, komiser), ticaret ve ekonomi (aksiyon, banka, bütçe, borsa, transit), kimya (arsenik, azot, amonyak, bor, gaz), yeni buluşlar ve teknolojik araçlar (asansör, balon, paratoner, kalorifer), askerî (obüs, batarya, roket, şarapnel, karabina), hukuk (avukat), ulaşım (istasyon, tren, fayton, kondüktör, vapur), giyim ve moda (iskarpin, broş, pardesü, palto, pantolon, manto), tekstil (bazen, patiska, pike, tül), spor ve oyun (eskrim, bezik, jimnastik, dama), tıp (iskorbüt, pomat, kangren), günlük eşya (lamba, panjur, kupa, lamba), fizik (elektrik), bitki ve sebze (enginar, domates), hayvan (balina, goril) gibi çeşitli alanlarla ilgili terim ve kelimeler, Fransızca ödünçlemeler arasında yer almaktadır.

KT'deki Fransızca alıntı kelimeler, fonolojik bakımdan çeşitli şekillerde Türkçeye uyarlanmıştır: istasyon $<$ Fr. station, istalaktit $<$ Fr. stalactite, iskorbüt $<$ Fr. scorbut, bâzen $<$ Fr. basin, paravan $<$ Fr. paravent, pardesü $<$ Fr. pardessus, palto $<$ Fr. paletot, duş $<$ Fr. douche, şose $<$ Fr. chaussée, salata $<$ Fr. salade, fasone $<$ Fr. façonne, kabine $<$ Fr. cabinet, perükâr $<$ Fr. perruquier vb. Bununla birlikte Şemseddin Sami, KT'de bazı Fransızca alıntı kelimelerin iki farklı yazımına yer verir: ataşe/ateşe $<$ Fr. attaché, entriga/entrika $<$ Fr. intrigue, pantolon/pantalon $<$ Fr. pantalon, pandomima/pantomima $<$ Fr. pantomime, raport/rapor $<$ Fr. rapport, santimetro/santimetre $<$ Fr. centimètre, stadiye/istadiye $<$ Fr. stadie, gangren/kangren $<$ Fr. gangrène, gorile/gorila $<$ Fr. gorille, kaloş/galoş $<$ Fr. galoche gibi. Standart olmayan bu tür ikili kullanımlar, Fransızca alıntı kelimelerin nispeten yakın zamanda ödünçlendiğinin ve fonolojik uyarlanma sürecinin tamamlanmadığının bir göstergesi olarak değerlendirilebilir.

KT'de belirlenen 241 Fransızca alıntı kelimeden 198'i tek anlamlıdır. Bu durum, KT'de yer alan kelimelerin daha çok terim niteliğinde oluşundan ve nispeten yeni ödünçlenmiş kelimeler olarak belirli bir ihtiyacı karşılamalarından kaynaklanır. Fransızcadan ödünçlenen kelimelerin bir kısmı kaynak dildeki temel ve ilk anlamıyla değil, ikincil ve yan anlamlarıyla Türkçeye dâhil edilmiştir. Örneğin Fransızca attaché kelimesinin temel anlamı "bağll, bağlanmış"tır. Kelime bu temel anlamla ilişkili olarak "bir elçiliğe bağlı uzman, görevli" şeklinde bir yan anlamı da ifade etmektedir. KT'de ataşe [Fr. attaché] kelimesi sadece "bir elçiliğe bağlı uzman, görevli" anlamıyla yer almaktadır. Kelime günümüzde de aynı anlamla kullanılmaktadır. Buna göre söz konusu kelime, Türkçeye temel anlamıyla değil, yan anlamıyla ödünçlenmiş ve bu şekilde yaygınlık kazanmıştır. Fransızcadan ödünçlenen istasyon [Fr. station] kelimesinde de aynı anlam özelliği görülmektedir. Çok anlamlı bir kelime olan station'un (istasyon) Fransizcada temel anlamı "durma, duraklama"dır. Kelimenin bu temel anlamından gelişen yan anlamlarından biri ulaşım araçlarının durduğu yeri karşılayan "durak"tır. Kelime Türkçeye temel anlamıyla değil, belirtilen yan anlamıyla ödünçlenmiştir. Aynı zamanda istasyon kelimesi Fransızcada metro, tren, taksi gibi çeşitli ulaşım araçlarının durduğu yer şeklinde

RumeliDE Dil ve Edebiyat Araştirmaları Dergisi Osmanağa Mahallesi, Mürver Çiçeği Sokak, No:14/8 Kadıköy - ISTANBUL / TÜRKIYE 34714 e-posta: editor@rumelide.com tel: +90 $5057958124,+902167730616$
Address

RumeliDE Journal of Language and Literature Studies

Osmanağa Mahallesi, Mürver Çiçeği Sokak, No:14/8

Kadıköy - ISTANBUL / TURKEY 34714

e-mail: editor@rumelide.com,

phone: +90 5057958124 , +90 2167730616 
genel anlama işaret ederken Türkçede sadece "demiryolu durăğ" anlamında ödünçlenerek bu şekilde yaygınlık kazanmıştır.

KT'de yer alan Fransızca alıntı kelimelerden bazılarına kaynak dilden tamamen farklı bir anlam yüklenmiştir. Örneğin Fransızca á bateau vapeur "buharlı gemi" şeklindeki tamlama, aynı anlamı karşılayacak şekilde Türkçeye kısaltılarak sadece vapur şeklinde ödünçlenmiştir. İki farklı kelimenin bir araya gelmesiyle oluşan bateau vapeur tamlamasında bateau "gemi", vapeur ise "buhar, buharlı" anlamını taşımaktadır. Buna göre Fransızcada "buhar, buharlı" anlamına gelen vapur kelimesi, Türkçede "gemi"yi karşılar şekilde kullanılmıştır.

\section{Kamus-ı Türkî'den günümüze Fransızca alıntı kelimelerde anlam değişmeleri}

$\mathrm{Bu}$ çalışmada KT'den günümüze Fransızca alıntı kelimelerdeki anlam değişmeleri, konuyla ilgili tipolojik çalışmalara uygun bir şekilde (bk. 2. bölüm) anlam genişlemesi, anlam daralması ve anlam aktarımı olmak üzere başlıca üç başlık altında incelenmiş; bunlardan anlam aktarımları ise oluşum şekilleri bakımından metafor, metonimi ve sinekdoka olmak üzere üç alt başlıkta değerlendirilmiştir. Blank'ın (1999) nesnel bir şekilde belirlenemedikleri için anlam değişmeleri tipolojisine dâhil etmediği anlam iyileşmesi ve anlam kötüleşmesi, bu anlayışa uyularak çalışmanın kapsamı dışında bırakılmıştır. Anlam olayları dışında, galatların da KT'den güncel Türkçeye meydana gelen anlam değişmelerinin bir nedeni olduğu tespit edilerek ayrı bir başlık altında incelenmiştir.

\subsection{Anlam genişlemesi}

Kelimenin anlam kapsamının genelleştirilmesiyle karakterize edilen anlam genişlemesi (İng. semantic expansion, widening, brodening, generalization), sözcüksel bir unsurun önceki/mevcut anlamını kaybetmeden anlam alanını genişletmesidir. Buna göre kelimenin anlamsal özelliklerinin sayısı azaltılarak kelime, daha fazla ve çeşitli bağlamda kullanılabilir hâle gelir (Campbell\&Mixco 2007: 222). Anlam genişlemesi, kelimenin tamamen yeni ek bir anlam kazanması veya şimdiye kadarki belirli bir anlamın genelleşmesiyle gerçekleşebilir.

KT'de daha özel ve dar anlama sahip bazı Fransızca alıntı kelimeler, güncel Türkçede daha genel ve geniş anlama işaret edecek şekilde anlam genişlemesi göstermektedir. Bu tür kelimelerde genellikle kelimenin KT'deki anlamı korunmakla birlikte bu anlama daha genel başka anlam/anlamların eklenmesi söz konusudur. Güncel Türkçede KT'den farklı olarak kelimelerin kazandıkları genel ve geniş anlam, çoğunlukla kaynak dil olan Fransızcada da bulunmaktadır. Buna göre, Fransızcayla dil temasının devam etmesi sonucu, 19. yüzyılda özel ve dar anlamıyla ödünçlenmiş kelimelerin daha genel ve geniş anlamları süreç içerisinde Türkçeye dâhil edilmiştir:

aksiyon [Fr. action]

Fransızca aksiyon kelimesi "davranış, tutum; iş, eylem; etki; çalışma, etkinlik; mücadele; şiirde konu; tiyatroda olay, olay akışı; hisse senedi, esham" gibi çeşitli anlamlar taşıyan çok anlamlı bir kelimedir. KT'de kelimenin "şirket ve ticaret hissesi" şeklinde tek anlamı bulunmaktadır. Güncel Türkçede ise KT'deki anlamın yanında kelime, Fransızca aslına uygun bir şekilde anlam genişlemesine uğrayarak "bir kuvvetin, maddi bir etkenin, bir düşüncenin ortaya çıması; insan etkinliğinin veya iradesinin ortaya çıkması; hareket, iş; bir oyuncunun hareketi; oyunun temasını geliştiren başlıca olay" gibi farklı anlamlar kazanmıştır.

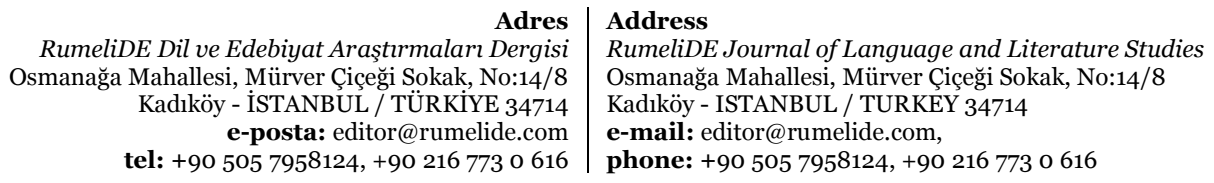


apolet [Fr. épaulette]

KT'de "askerlerin rütbe ve sinıflarına göre omuzlarına taktıkları saçak" anlamına gelen apolet kelimesi, Fransızcada "omuzluk, omuz askısı" şeklinde genel anlamlı bir kelimedir. 19. yüzyılda sadece askerî klyafetlerin bir bölümü için dar anlamıyla Türkçeye uyarlanan kelime, günümüzde orijinaline uygun bir şekilde anlam genişlemesi göstererek "giysilerin omuzlarına takılan omuzluk, omuz askısı" anlamında kullanılmaktadır.

\section{banderol (GTS bandrol) [Fr. banderole]}

KT'de Fransızcadan ödünçlenen bir kelime olarak yer alan banderol kelimesinin karşılığı, "tütün gibi ürünlerin paketlerine yapıştırılan damgalı kağıt" şeklindedir. Kelimenin Fransızcadaki temel anlamı "(gemi direğine çekilen ya da mızrak ucuna takılan) şerit şeklinde flama"dır. Bu anlamla ilişkili olarak kelime Fransızcada "tüfek kayışı; denetim pulu" gibi farklı anlamları da karşılamıştır. KT'de dar anlamıyla sadece "denetim pulu"nu karşılayan bir kelime olarak ödünçlenen bandrol, güncel Türkçede bu anlamın yanında "bayrak direğinin tepesine süs olarak konulan uzun, kumaş şerit" anlamı da kazanarak anlam genişlemesi göstermiştir.

\section{istasyon [Fr. station]}

"Demiryolu durağı" anlamıyla KT'de istasyon şeklinde geçen kelime, güncel Türkçede yaygın "demiryolu durağı" anlamının yanında "araştırma kuruluşu; satış, bakım, aşı vb. işler yapılan kuruluş veya yer" anlamlarını da taşımaktadır. KT'den günümüze anlam genişlemesine uğrayan istasyon kelimesinin kazandığı yeni anlamlar Fransızcada da bulunmaktadır.

\section{hartuç (GTS kartuş) [Fr. cartouche]}

KT'de "top fişeği" şeklinde tek anlamlı bir kelime olarak ele alınan hartuç kelimesi, güncel Türkçede fonolojik değişim göstererek kartuş olarak farklı kavramları karşılayan çok anlamlı bir kelimedir. GTS'de kelimenin ilk anlamı "merminin arkasından namluya sürülen bezden veya kartondan barut kesesi" olarak KT'deki kullanımına paralel olarak verilmektedir. Bu anlama ek olarak kartuş kelimesi, "dolma kalem içine yerleştirilen mürekkep dolu tüp; yazıcıya yerleştirilen mürekkep dolu tüp; resmi yazıda kralın adını diğerlerinden farklı bir biçimde göstermeyi sağlayan oval çerçeve" gibi farklı kavramları karşılayan çeşitli anlamlar da kazanmıştır. KT'den günümüze anlam genişlemesine uğrayan kelimenin, kavram alanının genişlemesinde ve yeni anlamlar kazanmasında kaynak dildeki anlam genişlemesi etkili olmuştur. Türkçe kartuş kelimesinin kaynağı olan cartouche kelimesi "sarmal şekilli süsleme; kağıt tomarı" anlamlarına gelir. Özellikle Mısır hiyerogliflerindeki karakterleri çevreleyen dikdörtgen figürlerle kağıt tomarının şekli arasındaki benzerlikten dolayı kelime aynı zamanda "sarmal şekilli süsleme" için kullanılmıştır. ${ }^{5}$ Bu açıklama kelimenin Türkçedeki "resmi yazıda kralın adını diğerlerinden farklı bir biçimde göstermeyi sağlayan oval çerçeve" anlamının kaynağını açıklar niteliktedir. Bununla birlikte "karton, teneke kutu, barut kutusu" anlamındaki Fransızca cartage kelimesi ile "kağıt tomarı" anlamındaki cartouche kelimesinin karışması sonucu "barut ve mermi içeren kap" anlamındaki cartridge kelimesi ortaya çımıştır. Cartouche kelimesi de "bezden veya kartondan barut kabı" anlamını taşımakla birlikte bu kelimeden oluşturulmuş cartridge kelimesi 20. yüzyıldan sonra İngilizcede "rulo şeklinde, içi doldurulabilir ve çalışmasını sağlamak için bir makineye koyulan kasa ve kap" şeklinde teknolojideki gelişmelerden doğan yeni nesneleri karşlayacak şekilde

5 https://www.etymonline.com/search?q=cartouche

\section{Adres}

RumeliDE Dil ve Edebiyat Araştırmalar Dergisi Osmanağa Mahallesi, Mürver Çiçeği Sokak, No:14/8 Kadıköy - İSTANBUL / TÜRKIYE 34714 e-posta: editor@rumelide.com tel: +90 $5057958124,+90216773$ o 616
Address

RumeliDE Journal of Language and Literature Studies

Osmanağa Mahallesi, Mürver Çiçeği Sokak, No:14/8

Kadıköy - ISTANBUL / TURKEY 34714

e-mail: editor@rumelide.com,

phone: +90 505 7958124, +90 216773 o 616 
anlam genişlemesi göstermiştir. ${ }^{6}$ Güncel Türkçede "dolma kalem veya yazıcı gibi aletlerin mürekkep doldurulabilen tüpü" anlamı, kelimenin özellikle İngilizce kanalıyla uğradığı anlam genişlemesinin dile dâhil edilmesi sonucu ortaya çıkmıştır.

reji [Fr. régie]

Fransızcadan ödünçlenen reji kelimesi KT'de tek anlamlı bir kelime olarak "tekel ürünlerin idaresi" şeklinde tanımlanır. Kelime GTS'de "tekel idaresi" anlamını korumakla birlikte "sinema, tiyatro, radyo ve televizyon oyunlarında oyunu yönetme"7 olarak farklı bir kullanım daha göstererek anlam genişlemesine uğramıştır.

salon [Fr. salon]

KT'de "evin misafir kabul etmeye mahsus en büyük ve en süslü odası; sergi yeri, gösteri yeri" olmak üzere başlıca iki anlam taşıyan salon kelimesi, güncel Türkçede de bahsi geçen anlamları korur. Bununla birlikte salon kelimesi, GTS'de "dükkan, mağaza" kavramlarını karşılayarak yeni bir anlam da kazanmış; anlam genişlemesine uğramıştır. Belirtilen anlamla "kuaför salonu, güzellik salonu, pide salonu" gibi kullanımları bulunan kelimenin anlamının genişlemesinde Fransızcadaki kullanımı etkili olmuştur. Kelimenin Franszıcadaki temel anlamı, "saray veya evde büyük oda"dır. Salon kelimesi 19. yüzyılda Fransızcada "Parisli kadınları kabul odası" ve bu kullanıma paralel bir şekilde "modaya uygun, şık insanların bir araya geldiği yer" anlamı kazanmıştır. 8 "Kuaförlük ve güzellik bakımı hizmeti veren yer" anlamı ise 20. yüzylın başlarında oluşmuştur. 9 Fransızcada salon kelimesi sadece "kuaför ve güzellik bakım yeri"ni karşılarken Türkçede farklı amaçlara hizmet eden mağazaları karşılamak için de kullanılmıştır (pide salonu, oyun salonu vb.). Salon kelimesinin "sergi ve gösteri yeri" anlamı ise Fransızcada Louvre müzesinin salonlarından birisinde resim ve heykel sergisi düzenlenmesinden doğmuş ve yaygınlık kazanmıştır. ${ }^{10}$

vize [Fr. visa]

Fransızcadan ödünçlenen vize kelimesi, KT'de "memur tarafindan görülmesi şart olan evraklara koyulan 'görülmüştür' işareti" olarak tanımlanmaktadır. GTS'de ise KT'deki anlam korunmakla birlikte kelime, "bir ülkeye girmek veya bir ülkeden çıkmak için yetkili makamlardan alınması gerekli izin; ara sınav" şeklinde farklı anlamlar da kazanmıştır. Vize kelimesinde, kaynak dil olan Fransızcaya uygun bir anlam genişlemesi görülmüştür.

KT'den güncel Türkçeye anlamın korunmasıyla birlikte yeni ve daha genel anlamların kazanıldığı anlam genişlemesi türü yanında, KT'deki Fransızca alıntı kelimelerin gösterdiği daha dar ve özel kapsamlı anlamın güncel Türkçede kullanımdan düşmesi ve aynı kelimenin daha genel ve geniş bir anlamda kullanılması da söz konusudur. Bu tür anlam genişlemesi örnekleri ilk grupta bahsedilen anlam genişlemelerinden daha azdır:

\footnotetext{
6 https://www.merriam-webster.com/dictionary/cartridge

Sermet Sami Uysal'a göre (2014: 203) Fransizca reji kelimesi, 1950'li ylllardan sonra Fransizca rejisör'ün [Fr. régisseur] kısaltması olarak "yöneten, yönetmen" anlamıyla Türkçede kullanılmaya başlamıştır. Bununla birlikte reji kelimesi, Fransızcada "yönetmen" değil, "tiyatro, sinema ve televizyon gösterilerinde sahne donanımını sağlayan kimse" anlamına gelir.

Salon kelimesinin KT ve GTS'de yer alan "şı, zarif, modaya uygun giyinen ve zarif davranış sergileyen kimse (salon
kadını, salon adamı)" olarak açklanabilecek baska bir anlam ve kullanımı da bulunmaktadır. Bu anlam yukarıda kadını, salon adamı)" olarak açılklanabilecek
açılandığı üzere Fransızcadan ödünçlenmiștir.

RumeliDE Dil ve Edebiyat Araştırmaları Dergisi Osmanağa Mahallesi, Mürver Ciçeği Sokak, No:14/8 Kadıköy - İSTANBUL / TÜRKIYE 34714 e-posta: editor@rumelide.com tel: +90 505 7958124, +90 2167730616

Address

RumeliDE Journal of Language and Literature Studies

Osmanağa Mahallesi, Mürver Çiçeği Sokak, No:14/8

Kadıköy - ISTANBUL / TURKEY 34714

e-mail: editor@rumelide.com,

phone: +90 505 7958124, +90 2167730616
} 
jüri [Fr. jury]

Fransızcadan ödünçlenen jüri, KT'de "bir suça karışanların gerçekten suçlu olup olmadıklarını veya hafifletici sebeplerin bulunup bulunmadığına karar vermek üzere toplanmış adlî heyet" olarak açıklanır. Kelimenin verilen tanımından da anlaşılacağı üzere KT'de jüri, bir hukuk terimi olarak "hakimler heyeti" anlamıyla kullanılmaktadır. Güncel Türkçede de yaygın bir kullanım alanına sahip olan jüri kelimesi, sadece "hakimler heyeti"ni değil, aynı zamanda genel anlamda "seçici kurul; hükümde bulunan heyet" anlamı da kazanmıştır. Kelimenin daha dar bir kavram alanından daha geniş ve genel bir anlam özelliği kazanması Fransızcada da söz konusudur.

\section{transport [Fr. transport]}

Fransızcada "(bir yerden bir yere) taşıma, iletme, nakletme; taşımacılık, nakliyat" anlamlarına gelen transport kelimesi, KT'de kaynak dildekinden daha dar anlamda bir matbaacılık terimi olarak "litografyada yazı veya resmin bir taştan diğerine nakli" olarak ele alınmaktadır. Kelime güncel Türkçede KT'deki kullanımından daha genel ve geniş bir anlamda, aslına uygun olarak "taşıma, nakil; taşımacılık, nakliyat" anlamlarında kullanılmaktadır.

KT'den günümüz Türkçesine tespit edilen üçüncü tür anlam genişlemesinde ise fonolojik özellikler de etkili olmaktadır. Bu tür anlam genişlemesinde, Fransızca kelimenin farklı fonolojik yapıyla farklı dönemlerde tekrar ödünçlenmesi veya farklı kaynaklar yoluyla dile yeniden dâhil edilmesinin etkin rol oynadığı düşünülebilir. Bununla birlikte, kelimenin kaynak dilden farklı bir fonolojik yapı ve anlam özelliğiyle alıcı dile yerleşmesi, süreç içerisinde kelimenin kaynak dildeki orijinal şekliyle bu kelime arasında ilişki kurmayı engeller. Böylece aynı kelime, farklı fonolojilerle aynı veya farklı anlamlarla tekrar ödünçlenir:

arş/marş [Fr. marché]

KT'de $a r r^{11}$ şeklinde "asker taliminde yürü komutu" olarak ele alınan Fransızca marché kelimesi, GTS'de aynı yazım ve anlamla korunmaktadır. Ancak GTS'de aynı Fransızca kelimenin, orijinal telaffuzuna daha yakın şekli olan marş da ayrı bir madde başı olarak yer almaktadır. Buna göre Fransızca marché kelimesi, farklı zamanlarda farklı telaffuz ve yazım özellikleriyle ödünçlenmiş; daha yeni şekil olan marş, arş kelimesinden farklı yeni anlamlar kazanmıştır. "Asker taliminde yürü komutu" anlamına ek olarak kelime, "motorlu araçları çalıştırma, işletme; bir topluluğu simgelemek için düzenlenmiş müzik parçası1" gibi anlamlar kazanarak anlam genişlemesine uğramıştır. Aynı anlam çeşitliliği ve kullanım özellikleri, Fransızcada da söz konusudur.

debboy/depo [Fr. dépôt]

Fransızcadan ödünçlenen debboy, KT'de "silah ve giysilerin konulduğu askerî ambar" anlamını taşımaktadır. Kelime aynı fonolojik ve anlamsal özelliklerle güncel Türkçede de korunmaktadır. Bununla birlikte aynı kelimeden daha sonra veya başka bir şekilde yapılan bir ödünçlemeyle kelime

$11 \quad$ Fransizca marché kelimesinin KT'de ve GTS'de bulunan arş şekli Sermet Sami Uysal'a göre (2014: 146), III. Selim döneminde, Osmanlı ordusunu yeniden düzenlemek için görevlendirilen Fransız subaylarının askerlere "yürü" komutu verirken kelimenin vurgusunu "arche" kısmı üzerinde yoğunlaştırmaları ve kelime başındaki /m/ sesinin duyulmamasindan kaynaklanmaktadır.

12 Temel anlamı "yürüme, yürüyüş; çalışma, işleyiş" olan marş [Fr. marché] kelimesinin "genellikle bir topluluğu simgelemek için düzenlenmiş müzik parçası" gibi farklı bir anlam kazanmasında, bu tür müzik parçalarının ritminin yürüyen bir kimsenin veya topluluğun adımlarının çıkardığı sese benzemesi veya askerî yürüyüş, geçit gibi resmî törenlerde bu tür müzik parçalarının icra edilmesi gibi bir ilişki kurulabilir.

\section{Adres $\mid$ Address}

RumeliDE Dil ve Edebiyat Araşttrmaları Dergisi $\quad$ RumeliDE Journal of Language and Literature Studies Osmanağa Mahallesi, Mürver Çiçeği Sokak, No:14/8 Osmanağa Mahallesi, Mürver Çiçeği Sokak, No:14/8

Kadıköy - İSTANBUL / TÜRKIYE 34714 Kadıköy - ISTANBUL / TURKEY 34714 e-posta: editor@rumelide.com

e-mail: editor@rumelide.com

tel: +90 5057958124, +90 2167730616 phone: +90 505 7958124, +90 2167730616 
depo şeklinde Türkçeye dâhil edilmiştir. debboy kelimesiyle aynı kökten ödünçlenen depo kelimesi güncel Türkçede KT'deki debboy kelimesinin anlamını korumakla birlikte, sadece askerî malların saklandığı yer değil, daha genel bir anlamda "korunmak, saklamak veya gerektiğinde kullanılmak için bir şeyin konulduğu yer" şeklinde anlam genişlemesi göstererek kaynak dildekine paralel bir şekilde daha genel bir anlam kazanmıştır.

nota/not [Fr. note]

Müzik terimi olarak Fransızcadan ödünçlenen nota kelimesi KT'de "müziğe özgü işaret; bu işaretlerle yazılmış ahenk" şeklinde tanımlanır. Aynı anlam güncel Türkçede de yaygın bir şekilde kullanılmakla birlikte kelime; "muhtıra, herhangi bir şeyi hatırlatmak, bir konuda uyarmak amacıyla yazılan yazı (özellikle diplomaside)" şeklinde KT'de bulunmayan yeni bir anlamı karşılayarak anlam genişlemesine uğramıştır. Nota kelimesi kaynak dil olan Fransızcada "im, işaret; unutmamak için yazılan kısa yazı; bir konuda yapılan kısa değerlendirme yazısı; ders için yazılan kısa ve özlü bilgi; öğretmenlerin verdiği derece; küȩük haber, haber pusulası; muhtıra; müzik işareti, nota" gibi farklı anlamlar taşımaktadır. KT ve GTS'de kelimeyi karşılayan anlamlar kaynak dildekine paralel olmakla birlikte, KT'den sonraki bir dönemde Fransızcadan veya başka bir kaynak dil üzerinden (İngilizce) note kelimesi, not şeklinde farklı bir telaffuz ve yazımla Türkçeye tekrar ödünçlenmiştir. Nota kelimesiyle aynı köke (note) dayanan not kelimesi; güncel Türkçede kaynak dilde bulunan ancak nota kelimesinin karşılamadığı "bir şeyi hatırlatmak için yazılan kısa yazı; öğretmenler tarafından verilen derece, sayı" gibi anlamları karşlar.

\section{pancur (GTS panjur/abajur) [Fr. abat-jour]}

Aynı Fransızca kelimenin farklı dönemlerde ve farklı fonolojik özelliklerle Türkçeye ödünçlenmesi sonucu ortaya çıkan anlam genişlemesine bir diğer örnek panjur ve abajur kelimeleridir. KT'de Fransızca abat-jour kelimesine dayandırılan pâncûr/pancûr "ışı̆̆ önlemeye yarayan, açılır kapanır pencere kafesi" anlamını taşımaktadır. Abat-jour kelimesinin Fransızcada karşıladığı anlam ise "baca, tepe camı; güneş siperliği; kepenk; lamba siperi" şeklindedir. Türkçede bulunan Farsça kökenli pencere ile Fransizca abat-jour kelimesi arasındaki hem fonolojik hem de iki kavramin anlam alanında bulunan benzerlikten yola çıkılarak bulaşma (İng. contamination) sonucu Türkçede pancur/panjur kelimesi üretilmiştir. Bununla birlikte, Fransizca abat-jour kelimesinin abajur şeklinde kaynak dile uygun bir şekilde ödünçlenmiş şekli de Türkçede mevcuttur. Abajur kelimesi, panjur kelimesinden farklı olarak "ışığın doğrudan göze vurmasını önlemek için yapılmış lamba siperi; siperli masa lambası veya ayaklı lamba" anlamlarını kazanmıştır.

\subsection{Anlam daralmasi}

Anlam daralması (İng. semantic narrowing, restriction, specialization), kelimenin kullanılabileceği anlamsal kapsamın veya bağlamın kısıtlanması; anlamsal alanın özelleştirilmesidir (Bussmann 1999: 1041-1042). Kelimelerin anlam açısından daha az genel veya daha az kapsayıcı hâle geldiği anlam daralması, kelimenin belirli ve sınırlı bir bağlamda kullanılmasını karşılar (Campell\&Mixco 2007: 133).

KT'de yer alan Fransızca alıntı kelimelerden bir kısmı, daha genel ve kapsayıcı anlamını yitirerek güncel Türkçede kullanılmaktadır. Bu tür anlam daralmalarında, kelimenin diğer anlam/anlamları korunurken bazıları kullanımdan düşmüştür:

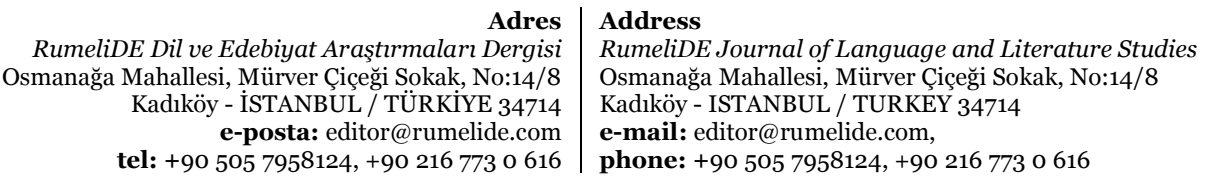


balina [Fr. baleine]

KT'de Fransızcadan ödünçlenmiş bir kelime olarak yer alan balina, üç farklı anlam taşımaktadır: "Kadırga balığı da denilen denizde yaşayan büyük memeli hayvan; bu hayvanın çeşitli eşya yapımında kullanılan kemikleri; giysilerin dik ve düzgün durması için özellikle yakalara konulan çubuk". Kelime güncel Türkçede KT'de verilen birinci ve üçüncü anlamı korumakla birlikte metonimik bir anlam ilişkisiyle oluşturulmuş olan "balinanın çeşitli eşya yapımında kullanılan kemikleri" anlamını kaybederek anlam daralmasına uğramıştır.

\section{batarya $[\mathrm{Fr}$. batterie]}

Batarya kelimesi Fransızcada "kavga; savaş; takım, eşya takımı; savaş gemilerinin topları ve bunların bulunduğu yer; vurmalı çalgı; pil13" gibi farklı anlamlar taşır. Fransızcadan askerî bir terim olarak ödünçlenen batarya kelimesinin KT'de iki farklı anlamı vardır. Kelimenin temel anlamı "altı top ile asker ve çeşitli ekipmandan oluşan takım" iken aynı kelimenin mecazi anlamı "sert muamele, şiddetli bir şekilde azarlama (bataryayı yemek)" olarak verilmiştir. Buna göre, batarya kelimesi, 19. yüzyılda orijinal dildeki anlamına göre daha dar bir anlamla Türkçeye uyarlanmıştır. Bununla birlikte, "sert muamele, şiddetli azarlama" şeklinde Fransızcada bulunmayan metaforik anlamın oluşmasında ise kelimenin ödünçlendiği dildeki temel anlamı olan "kavga; dövme; savaş" anlamları etkili olmuştur. Kelime GTS'de KT'dekinden farklı olarak hem daha genel anlamlar kazanmış hem de biraz yukarıda ifade edilen metaforik anlamını kaybederek anlam daralmasına uğramıştır. GTS'de batarya kelimesi, "en küçük topçu birliği; savaş gemilerinde borda topları ve bunların bulunduğu güverte parçası; birkaç aygıtın bir araya getirilerek belirli bir biçimde eklenmesinden oluşan takım; pil" gibi çeşitli anlamlara gelir. Bu anlamların büyük bir çoğunluğu, kelimenin Fransızcadaki kullanımıyla örtüşür. Güncel Türkçede Fransızca batterie kelimesinden gelen, fakat batarya'dan farklı fonolojik özelliklere sahip "vurmalı çalgılar"ı karşılayan bateri kelimesi de bulunmaktadır. Batarya kelimesiyle aynı Fransızca kelimeye dayanan bateri kelimesi, daha sonraki bir dönemde Fransızcadan veya başka bir kaynak dilden (İngilizce) Türkçeye ödünçlenmiş olmalıdır.

ceneral (GTS general) [Fr. général]

Ceneral kelimesi, KT'de "yüksek rütbeli asker kumandanı; umumi, baş" şeklinde iki anlamı ifade etmektedir. Fransızca telaffuzuna uygun bir şekilde KT'de ceneral şeklinde verilen kelime, güncel Türkçede Almanca telaffuzuyla general ${ }^{14}$ şeklinde kullanılmakta ve sadece "askeriyede yüksek rütbeli subaylara verilen genel ad" olarak tanımlanmaktadır. KT'de kelimenin sahip olduğu "umumi, baş" anlamı, güncel Türkçede kullanımdan kalkmış; dolayısıyla kelime anlam daralmasına uğramıştır.

fabrika [Fr. fabrique]

Fransızcadan ödünçlenen fabrika kelimesinin hem KT'de hem de GTS'de temel anlamı "çeşitli maddelerin makine yardımıyla işlenerek kullanıma hazır hâle getirildiği yer, üretim yeri" şeklinde açıklanmaktadır. Bununla birlikte, KT'de kelimenin "gazetecilikte yalan, uydurma haber" olarak ifade

13 İlk defa 1748'de Amerikalı bilimadamı Benjamin Franklin, batarya [Fr. batterie] kelimesini "pil"in karşllı̆̆ olarak kullanmıștır (https://www.etymonline.com/search?q=batterie). Elektrik hücresi șeklinde kelimeye yeni bir anlam kazandıran Franklin, "elektriğin toplanmasıyla" kelimenin "takım, birkaç parçadan oluşan birlik" anlamı veya "savaş gemilerinde topların bulunduğu güverte parçası" anlamıyla pil arasında bir anlam ilişkisi kurmuş olabilir.

14 Türkçedeki ceneral telaffuzu, kelimenin Fransızca telaffuzunu göstermektedir; general telaffuzu ise kelimenin Almancadaki telaffuzuna dayanır. $\mathrm{Bu}$ farklı telaffuzdan da anlaşlacağı üzere, kelime farklı zamanlarda hem Fransızcadan hem de Almancadan ödünçlenmiştir.

Adres $\mid$ Address

RumeliDE Dil ve Edebiyat Araştırmaları Dergisi $\quad$ RumeliDE Journal of Language and Literature Studies Osmanağa Mahallesi, Mürver Çiçeği Sokak, No:14/8 $\quad$ Osmanağa Mahallesi, Mürver Çiçeği Sokak, No:14/8

Kadıköy - İSTANBUL / TÜRKIYE 34714 Kadıköy - ISTANBUL / TURKEY 34714 e-posta: editor@rumelide.com tel: +90 505 7958124, +90 2167730616 phone: +90 505 7958124, +90 2167730616 
edilen bir mecazi anlamı bulunmaktadır. Kaynak dil Fransızcada da bulunan söz konusu mecazi anlam, güncel Türkçede kullanımdan düşmüş; kelime anlam daralmasına uğramıştır. Bununla birlikte fabrika kelimesi, güncel Türkçede GTS'de yer almayan "durmadan çalışma, hızlı ve sürekli iş yapma" olarak KT'dekinden farklı bir mecazi anlam taşımaktadır.

\section{kondüktör [Fr. conducteur]}

Fransızcadan ödünçlenen kondüktör kelimesi, KT'de "kılavuz, memur, müdür; tramvay omnibüs arabalarında bilet vermeye ve arabayı yürütüp durdurmaya memur adam" olarak anlamlandırılmıştır. Kelime GTS'de "kılavuz, memur, müdür" anlamını kaybederek, anlam daralmasına uğramıştır. Güncel Türkçede kondüktör, sadece "yolcu trenlerinde biletleri denetleyen ve vagon işlerine bakan görevli" anlamını taşımaktadır.

\section{salata [Fr. salade]}

Fransızcadan ödünçlenen salata kelimesinin KT'de üç anlamı vardır: "İştah açıcı olarak yemek arasında yenen tuzlu ve ekşili şey; bir tür marul; marulun tuz, sirke ve zeytinyăğyla terbiyelenmesiyle oluşan yiyecek". KT'den günümüze kelimenin bazı anlamları kullanımdan düşmüş, kelimenin anlam alanı daralmıştır. Kelimenin güncel Türkçede "genellikle bazı çiğ ot ve sebzelerle yapılan, yağ, limon vb. maddeler konulan, yemeklerle birlikte yenen yiyecek" şeklinde tek anlamı bulunmaktadır. Eski Fransızcada "tuzlanmış sebze, salamura edilmiş sebze" anlamı taşıyan salata kelimesi15, güncel Fransızcada "sebze, meyve gibi çeşitli yiyeceklerin karıştırılmasıyla hazırlanan soğuk yemek" anlamını kazanmıştır. Bununla birlikte salata kelimesi, Fransızcada, belki bu sebzenin salata malzemesi olarak sıklıkla kullanılmasından dolayı, "kıvırcık marul"u da karşılamaktadır. Kelimenin KT'de tespit ettiğimiz bu kullanımı, bugün yerini "kıvırcık marul" veya daha yaygın şekilde bu ifadenin kısaltılmış şekli olan "kıvırcık" kelimesine bırakmıştır. Günümüzde hıyar karşllı̆̆ olarak yaygın ve genel bir kullanıma sahip salatalık kelimesi de aynı köke dayanmaktadır. Bu kelimenin oluşumunda salata kelimesinin "tuzlanmış, salamura edilmiş sebze" dolayısıyla "turşu" şeklindeki ilk anlamı (salatalık hıyar > turşuluk hıyar), turşu veya salata yapımında hıyarın sıklıkla kullanılmasının etkili olduğu düşünülebilir.

KT'deki bazı anlamların güncel Türkçede kullanımdan düşmesi dışında, kelimenin anlam kaybına uğramadan daha dar ve özel bir anlamda kullanılması da söz konusudur:

\section{gardiyan [Fr. gardien]}

Fransızcadan ödünçlenen gardiyan kelimesi KT'de kaynak dildeki anlamına paralel bir şekilde "kolcu, nöbetçi, muhafız" şeklinde anlamlandırılmaktadır. Aynı kelime GTS'de "cezaevlerinde düzeni, tutukluların kurallara uygun biçimde davranmalarını sağlamakla görevli kimse" şeklinde daha dar bir kavram alanı içerisinde tanımlanır. Başka bir deyişle, KT'de gardiyan kelimesi genel olarak "koruma, gözetleme görevi yapan kişi" anlamına gelirken güncel Türkçede sadece "cezaevi görevlisi" olarak dar anlamda kullanılmaktadır.

KT'den günümüze Fransızca alıntı kelimelerin anlam daralması yoluyla yeni anlamlar kazandığı veya tek anlamlıdan çok anlamlı kelimelere dönüştüğü örnekler de mevcuttur:

15 https://www.etymonline.com/search?q=salade 


\section{cimnastik (GTS jimnastik) [Fr. gymnastique]}

Fransızcadan ödünçlenen bir kelime olarak KT'de yer alan cimnastik kelimesi "vücudu kuvvetlendirmek için yapılan fiziksel idman" olarak tanımlanmaktadır. Jimnastik şeklinde güncel Türkçede de yaygın bir şekilde kullanılan kelime, KT'deki anlam özelliğini korumakla birlikte "erkeklerde ve kadınlarda çeşitli alıştırmaları içeren spor dalı" şeklinde başka bir anlam daha kazanmıştır. Jimnastik kelimesi KT'de "vücudu çalıştırmak için yapılan her türlü fiziksel alıştırma"nın genel adı olarak kullanılırken bu kullanıma ek olarak güncel Türkçede "belirli hareketleri içeren bir spor dalı" olmak üzere daha dar ve özel bir anlama da işaret etmektedir.

\section{kostüm [Fr. costume]}

Fransızcadan ödünçlenen kostüm, KT'de orijinal dildeki anlamına uygun bir şekilde "kıyafet, giysi; ceket, pantolon ve yelekten oluşan takım elbise" şeklinde anlamlandırılmıştır. Kelime GTS'de bahsi geçen anlamları korumakla birlikte, "sinema ve tiyatroda rol gereği giyilen özel amaçlı kıyafet" anlamını da kazanmıştır. Buna göre kostüm kelimesi, KT'deki anlamından (kıyafet, giysi) farklı, daha dar ve özel başka bir anlam (sinema ve tiyatroda kullanılan özel amaçlı kıyafet) kazanmıştır.

\subsection{Anlam aktarımı}

Mecazi anlama işaret eden anlam aktarımı (İng. semantic shift); benzerlik, yakınlık ve ilişkili olmayla ilgili olarak ortaya çıkarılan anlamlardır. Cruse'a (2006: 63) göre mecazi anlam, kelimenin gösterdiği gerçek anlamdan farklı anlamları ifade etmesidir ve genel olarak anlam genişlemesi ilkeleri temelinde anlaşılabilir. Kelimenin temel anlamından doğan yeni mecazi anlamlar; metafor, metonimi ve sinekdoka olmak üzere üç başlık altında incelenebilir.

\subsubsection{Metafor}

Mecazi bir ifade şekli olan metafor, iki nesne veya kavram arasındaki benzerlik ilişkisine dayanan dilbilimsel imajlardır. Cruse (2006: 106), metaforu açık bir şekilde ifade edilmeyen kısaltılmış benzerlik ve analoji ilişkisi olarak tanımlar. Buna göre, metafor, kelimenin gerçek anlamı ile gizli veya açı benzerlik veya kavramsal paralelliğe dayalı olarak yeni bir anlamın üretildiği durumdur. Metafor, bir tür şeyi, bazı açlardan benzer, ilişkili veya bağlantılı olduğu düşünülen başka türden bir şey açısından anlama veya deneyimlemeyi içeren bir anlam değişimidir.

KT'de sadece temel anlamlarıyla yer alan bazı Fransızca alıntı kelimeler, güncel Türkçede bu anlamlara ek olarak yeni metaforik anlamlar kazanmıştır. Bu metaforik anlamlar, büyük oranda Fransızcayla paralellik gösterir. Başka bir deyişle, aynı metaforik anlamlar Fransızcada da mevcuttur. Bu tür metaforik anlamların süreç içerisinde dil temasının devam etmesi sonucu Türkçeye dâhil edildiği düşünülebilir. Bununla birlikte, diller arasında etkileşim olmaksızın kavramlar arasında benzer zihnî süreçlerin işletilmesiyle aynı kelimelerin farklı dillerde benzer metaforik anlamlara işaret etmesi de mümkündür. Ancak alıntı kelimelerde, kaynak dildekiyle benzer bir metaforik anlamın ödünçleme yoluyla mı oluştuğunu yoksa dilin kendi anlam yapısından mı ortaya çıtı̆̆ını belirlemek neredeyse imkânsızdır:

abone [Fr. abonné]

\begin{tabular}{r|l} 
Adres & Address \\
RumeliDE Dil ve Edebiyat Araşttrmaları Dergisi & RumeliDE Journal of Language and Literature Studies \\
Osmanağa Mahallesi, Mürver Çiçeği Sokak, No:14/8 & Osmanağa Mahallesi, Mürver Çiçeği Sokak, No:14/8 \\
Kadıköy - İSTANBUL / TÜRKIYY 34714 & Kadıköy - ISTANBUL / TURKEY 34714 \\
e-posta: editor@rumelide.com & e-mail: editor@rumelide.com, \\
phone: +90 505 7958124, +90 2167730616
\end{tabular}


KT'de "gazete ve dergi gibi süreli yayınlara parasını önceden ödeyerek belirli bir süre sürdürümcü olan kimseyi" karşılayan abone kelimesi, GTS'de de aynı anlamı korumaktadır. Ancak kelime, bahsi geçen anlama ek olarak, güncel Türkçede "bir işi yapmayı veya bir yere gitmeyi alışkanlık hâline getiren kimse" şeklinde metaforik bir anlam kazanmıştır. Aynı anlam ilişkisi, Fransızcada da söz konusudur.

aktör [Fr. acteur]

KT'de "erkek tiyatro oyuncusu" anlamına gelen Fransızca aktör kelimesi, GTS'de de aynı anlam ve kullanım özelliğiyle yer almaktadır. Ancak kelime, ifade edilen temel anlamının yanında güncel Türkçede "herhangi bir olayda etkisi veya katkısı olan kimse" şeklinde metaforik bir anlam kazanmıştır.

\section{balkon [Fr. balcon]}

Fransızcadan ödünçlenen balkon kelimesi, KT'de genel bir şekilde "üstü açı ve geniş pencere çıkıntısı" şeklinde açıklanmıştır. Kelime, aynı anlam özellikleriyle güncel Türkçede de kullanılmaktadır. Bununla birlikte balkon, güncel Türkçede, özellikle argo kullanımda, "vücudun göğüs veya göbek bölümü, vücudun ön kısmındaki çıkıntı" anlamıyla metaforik bir anlam da kazanmıştır. Aynı anlam ilişkisi, Fransızcada da görülmektedir.

balon [Fr. ballon]

Fransızcadan ödünçlenen balon kelimesi, KT'de "havadan hafif bir gazla atmosferde uçabilen hava gemisi, hava taşıtı; gazla doldurulmuş çocuk oyuncă̆ı" olmak üzere iki farklı nesneyi karşılayan bir anlamda kullanılmaktadır. Kelimenin Fransızcada temel anlamı; "büyük top (basketbol topu, futbol topu vb.)"tur. Bununla birlikte "top"un şekli ve özellikleriyle kurulan ilişki sonucu kelime, Fransızcada "hava taşıt aracı; çocuk oyuncağı; yuvarlak bardak; yuvarlak tepe" gibi farklı anlamlar da kazanmıştır. Güncel Türkçede balon kelimesi KT'deki anlam özelliklerini (hava taşıt aracı; çocuk oyuncağı) korumakla birlikte Fransızcadakine benzer bir şekilde "karnı yuvarlak şişkin cam kap; karikatürde içi sözle doldurulan yuvarlak" gibi metaforik anlam özelliklerine sahip olmuştur. Bununla birlikte, kelime güncel Türkçede KT'de görülmeyen "aslı olmayan söz, palavra" şeklinde metaforik bir anlam da kazanmıştır.

goril [Fr. gorille]

Fransızcadan ödünçlenen goril kelimesinin temel anlamı, hem KT'de hem de GTS'de "büyük ve kuvvetli bir tür maymun" şeklindedir. Kelime güncel Türkçede, bu kullanımına ek, insana ait özellikleri karşılayan bir nitelikte metaforik olarak "koruyucu" anlamı kazanmıştır. Bu metaforik anlam, kaynak dil olan Fransızcada kelimenin "büyük ve kuvvetli bir tür maymun" anlamı yanında gösterdiği "önemli devlet adamlarının özel koruması" kullanımından doğmuş olmalıdır.

kanal [Fr. canal]

"Doğal yolla oluşmuş veya insan eliyle yapılmış su yolu" anlamıyla KT'de yer alan kanal kelimesi, güncel Türkçede aynı anlamı korumakla birlikte "telefon, telgraf, radyo, televizyon vb. araçlarla iletişimi sağlayan yol, hat; içinde damar, sinir veya bir sıvı geçen yol" gibi yeni anlamlar da kazanmıştır. Metaforik yolla oluşan bu anlam ilişkisi, kaynak dil olan Fransızcada da söz konusudur.

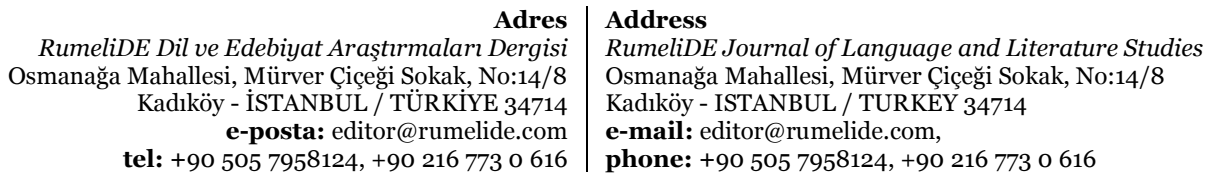




\section{kaput [Fr. capote]}

Fransızcada "yağmurluk, palto; kadın şapkası; (gemilerde) eşya örtüsü, eşya kılıfı; arabanın motor kapağı" gibi çeşitli anlamlara gelen kaput kelimesine KT'de "asker paltosu, yağmurluğu" karşıllğı verilmiştir. GTS'de ise KT'deki "asker paltosu" anlamına ek olarak kaput kelimesi, metaforik olarak "motorlu taşıtlarda motoru örten açılır kapanır biçimdeki kapak; prezervatif" anlamlarını da taşımaktadır. Dar anlamıyla (yağmurluk > asker yağmurluğu) ödünçlenen kelime, daha sonraki dönemlerde Fransızcada geçirdiği anlam değişmesiyle Türkçeye dâhil edilmiştir.

\section{kumanda [Fr. commandé]}

Askerî bir terim olarak Fransızcadan ödünçlenen kumanda kelimesi KT'de "askere verilen emir, askeri idare etme, kumandanlık; amir, amirlik, hüküm" şeklinde tanımlanmaktadır. Kelime aynı anlamı güncel Türkçede de korumakla birlikte, metaforik olarak "elektronik aygıtları belli bir uzaklıktan yönetmeye yarayan kablosuz alet" şeklinde yeni bir anlam da kazanmıştır. Teknolojideki gelişmelerle birlikte 20. yüzyılda "emretme, idare etme, yönetme" sadece insana ait bir özellik olmaktan çıkarak elektronik eşyaların da taşıdığı bir nitelik hâline gelmiştir. Böylece uzaktan komut verebilen cihazlar "elektronik kumanda cihazı" şeklinde tanımlanmış; yaygın kullanım sonucu "kumanda" olarak kısaltılmıştır. Aynı anlam ilişkisi, Fransızca için de geçerlidir.

\section{kupa [Fr. coupe]}

Fransızcadan ödünçlenen kupa kelimesine KT'de "cam bardak; bu bardağın alabileceği miktar; oyun kağıtlarının kalp biçimli, beneklisi" karşılıkları verilmiştir. Kelime aynı anlamlarla güncel Türkçede de yaygın bir şekilde kullanılmaktadır. Bununla birlikte, kupa kelimesi GTS'de KT'de bulunmayan "yarışma ödülü olarak verilen kap" anlamı da taşır. Metaforik anlam ilişkisiyle oluşturulan bu anlam, Fransızcada da görülmektedir.

\section{paravan [Fr. paravent]}

Fransızcadan ödünçlenen paravan kelimesine KT"de "kapının içine veya dışına takılan katlanır çerçeve" anlamı verilmiştir. Kelime aynı anlamla GTS'de de yer almaktadır. Bu anlama ek olarak kelime, güncel Türkçede "adından, yetkisinden, gücünden kendisine belli etmeden yararlanılan" anlamıyla metaforik bir anlam kazanmıştır. Aynı metaforik anlam, Fransızcada da bulunmaktadır. Bununla birlikte Türkçede paravan anlamına gelen paravana şeklinde bir kelime daha vardır. Paravana kelimesi, Fransızca paravent kelimesinin İtalyancadaki karşllı̆̆ olan paravènto ${ }^{16}$ kelimesinden veya yine Fransızcadan farklı fonolojik şekille ödünçlenmiş olmalıdır.

sahne [Fr. scéne]

Şemseddin Sami tarafından Fransızca scéne kelimesinin karşılığı olarak Arapça sahn "sahanlık, düzlük alan" kelimesinin fonolojisine uydurularak üretilen sahne kelimesi, KT'de "tiyatro gösterisinin yapıldığı yer" olarak tanımlanır. Güncel Türkçede KT'deki temel anlamı korunmakla birlikte, 20. yüzyılda tiyatronun yanı sıra sinemanın gelişmesiyle kelimenin kavram alanı zenginleşmiştir. "Görüntü; bir konu veya çalışma çevresi, çalışma dalı; bir oyun veya filmin başlıca bölümlerinden her biri" gibi farklı kullanımlar kazanan sahne kelimesinin anlamı genişlemiştir. Bununla birlikte, kelime

16 https://www.treccani.it/vocabolario/paravento 
KT'de olmayan "tanık olunan, gözlenen olay" şeklinde metaforik bir anlam da kazanmıştır. Sahne kelimesinin gösterdiği bu anlam çeşitliliği, Fransızcada da söz konusudur.

şık [Fr. chic]

KT'de "güzel, zarif, hoş edalı; modaya uygun, süslü" gibi anlamlar taşıyan şık kelimesi, güncel Türkçede de yaygın bir şekilde kullanılır. Kelime GTS'de "güzel, zarif, modaya uygun; güzel, modaya uygun giyinmiş olan" şeklinde açıklanmakla birlikte metaforik olarak "yerinde, uygun" kavramını da karşılayan bir anlam özelliği göstermektedir. Türkçede genel kullanım olarak modayla ilgili bir kavramı karşılayan kelimeden, "modaya uygun" olma özelliği ve "güzel, hoş" kavramlarıyla ilişkili olarak daha genel anlamlı bir metaforik ifade doğmuştur. Bununla birlikte, kelimenin Fransızcadaki temel anlamı; "beceri, (özellikle sanat ve resimde) maharet"tir. Kelime ilk defa 19. yüzyılda İngilizcede "Fransız tarzı zarafet ve moda" için bir sıfat olarak kullanılmışs ve daha sonra bu anlam Fransızca da dâhil, kelimeyi ödünçleyen pek çok dilde bu kullanımıyla yaygınlaşmıştır.

Güncel Türkçede bazı kelimelerin KT'deki kullanımından farklı olarak kazandıkları yeni metaforik anlamlar, kaynak dil olan Fransızcada bulunmaz. Bu tür kelimelerin ifade ettiği metaforik anlamlar Türkçeye özgüdür:

banker [Fr. banquier]

"Banka sahibi, banka idare eden büyük sarraf" anlamıyla KT'de yer alan banker kelimesi, güncel Türkçede aynı anlamı korumakla birlikte metaforik olarak "çok zengin kimse"yi karşılayacak bir anlam da ifade etmektedir. Türkçede "milyoner, milyarder, trilyoner" gibi kelimeler zenginlik kavramını belirtir. Bahsi geçen kelimelerle banker arasındaki fonolojik benzerliğin (-er) kelimenin analoji yoluyla "zenginlik" şeklinde metaforik bir anlam kazanmasında etkili olduğu düşünülebilir (Uysal 2014: 150).

elektrik [Fr. électrique]

KT'de elektrik şeklinde "bazı cisimlerin sahip olduğu, her şeyi kendine çekme özelliği" olarak açıklanan kelime, güncel Türkçede temel anlamı ve bu anlamla ilişkili olarak teknolojik gelişmeler sonucu elektrik enerjisinin kullanım özellikleri ve alanlarını yansıtan metonimik anlamlar kazanmıştır. Bununla birlikte, elektrik kelimesi, güncel Türkçede "çarpıcılık, cazibe, canlılık, etkileyicilik" gibi metaforik bir anlamı da belirtmektedir. Bu anlam özelliği, Fransızcada görülmemektedir. Fransızcada elektrik kelimesi metaforik olarak "sinir gerginliğini, gerginliği" ifade etmektedir. Her ne kadar GTS'de yer almasa da elektrik kelimesinin Fransızcadakine benzer şekilde metaforik kullanımı Türkçede de söz konusudur.

candarma (GTS jandarma) [Fr. gendarme]

Jandarma kelimesi, hem KT'de hem de GTS'de "asayişi sağlanmakla görevli, maaşlı askerî kuvvet" olarak kaynak dildeki anlamına uygun bir şekilde askerî bir terim olarak Fransızcadan ödünçlenmiştir. Söz konusu kelime, güncel Türkçede bahsi geçen anlama ek olarak "açıkgöz" şeklinde metaforik bir anlam kazanmıştır. Kelimenin Türkçede ifade ettiği bu metaforik anlam, kaynak dil olan Fransızcada görülmemektedir.

17 https://www.etymonline.com/search?q=chic 
misket [Fr. mousquet]

KT'deki Fransızca alıntı kelimelerden biri olan misket, "geniş çaplı eski bir tüfek türü ve misket tanesi" olmak üzere iki farklı anlam taşır. Kelime Fransızcada sadece "fitilli bir tüfek" türünü karşılar. Buna göre, misket KT'de metonimik bir anlam genişlemesine uğrayarak hem tüfeği (alet) hem de bu tüfekle atılan kurşun tanelerini (parça) karşılar. Kelimenin "tüfek" anlamı GTS'de kullanımdan kalkmış, kelime sadece "bomba ve şarapnellerin içinde bulunan kurşun veya demir taneler" anlamını karşılamaya başlamıştır. Bu anlam kaybında, misket tüfeğinin teknolojik gelişmeler ve yenilikler sonucu kullanımının azalmasının etkili olduğu düşünülebilir. Misket kelimesi, sahip olduğu anlamlardan birini kaybederken "misket tanesi" anlamından iki kavram arasındaki şekil benzerliğinden metaforik olarak "bilye" anlamı doğmuştur.

paket [Fr. paquet]

Fransızcadan ödünçlenen paket kelimesi, KT'de "birlikte bağlanmış veya kağıda sarılmış eşya demeti" şeklinde anlamlandırılmaktadır. Kelime aynı anlamı güncel Türkçede de korumakla birlikte, özellikle argo kullanımda metaforik olarak "dolu (toplu taşım aracı)" anlamı kazanmıştır. Kelimenin Türkçe eklerle işletilerek oluşan paketlemek şekli de "bir veya birkaç şeyi kağıda sararak, kutuya koyarak bağlamak" temel anlamı dışında "yakalamak, ele geçirmek, derdest etmek; birini baştan savmak, atlatmak" gibi metaforik anlamlara sahiptir. Kaynak dil Fransızcada kelimenin bu anlamı taşıyan metaforik bir kullanımı bulunmamaktadır.

sivil [Fr. civil]

Fransızcadan ödünçlenen sivil kelimesi, KT'de "asker dışındaki halk; askerî kıyafet dışındaki kıyafet; üniformasını giymemiş polis memuru" anlamlarına gelir. Aynı anlamlandırış güncel Türkçe için de geçerlidir. Bununla birlikte kelime, güncel Türkçede argo olarak "çıplak, çırılçıplak" kullanımı da gösterir. Metaforik olarak oluşturulmuş bu anlam Türkçeye özgüdür, Fransızcada kelimenin bu tür bir metaforik anlamı bulunmamaktadır.

\section{torpil [Fr. torpille]}

Fransızca kaynaklı torpil kelimesine KT'de verilen anlam, "savaş gemilerini parçalamak için elektrik vasıtasıyla deniz altında atılan büyük mermi" şeklindedir. Torpil 18 kelimesinin Fransızcada "başındaki bir organdan çıkardığı elektrikle avlayacağı balıkları öldüren bir balık türü, torpil balığı; savaş gemilerini batırmak için su altı silahı olarak kullanılan büyük bomba" olmak üzere iki anlamı bulunmaktadır. Torpil kelimesi, güncel Türkçede KT'deki anlamını korumakla birlikte bu anlama ek olarak "bir kimseyi kayırma, arka, destek çlkmak" gibi metaforik bir anlam da kazanmıştır. Fransızcada görülmeyen bu anlamın ortaya çıkışında, torpil bombasının "deniz altında, gizli" bir şekilde etki göstermesi metaforik anlam ilişkisinin kurulmasını sağlamış olabilir.

${ }_{18} \quad$ Fransızca torpille kelimesinin kökeni Latince torpedo kelimesine dayanır. Torpedo kelimesi, başlangıçta "avını sersemletmek veya kendini savunmak için elektrik üreten yassı balık" kavramını karşılamaktadır. 18. yüzyılda "düşman gemilerini parçalamak için patlayıcı bomba"nın icat edilmesiyle kelime bu yeni kavramın karşılığı olarak kullanılmaya başlamıstır (https://www.etymonline.com/search?q=torpedo). Ancak torpille kelimesinin yanı sıra torpedo kelimesi de aynı anlamla Franszıcada kullanılmaya devam etmiştir. Torpedo kelimesi, torpido şeklinde Türkçeye ödünçlenerek denizcilikte "torpido botu" veya "torpil" anlamıla kullanılmaktadır.

Adres Address

RumeliDE Dil ve Edebiyat Araşttrmaları Dergisi $\quad$ RumeliDE Journal of Language and Literature Studies Osmanağa Mahallesi, Mürver Çiçeği Sokak, No:14/8 Osmanağa Mahallesi, Mürver Çiçeği Sokak, No:14/8

Kadıköy - İSTANBUL / TÜRKIYE 34714 Kadıköy - ISTANBUL / TURKEY 34714 e-posta: editor@rumelide.com

e-mail: editor@rumelide.com

tel: +90 $5057958124,+90216773$ o 616 phone: +90 505 7958124, +90 216773 o 616 


\subsubsection{Metonimi}

Metonimi, çağrışım ilişkisiyle oluşturulan bir mecaz türüdür. Buna göre metonimi, varlık veya kavramın bir niteliğinin adının varlığın kendisi yerine kullanılması olarak tanımlanabilir (Crystal 2008: 303). Metafordan farklı olarak metonimi; benzerlik, karşılaştırma veya analoji ilişkisine dayanmaz (Cruse 2006: 108). Metonimik anlamı oluşturan çağrışımsal ilişki türleri çok çeşitlidir.

Güncel Türkçede Fransızca alıntı kelimelerin bir kısmı KT'deki anlam/anlamlarını korumakla birlikte farklı ve yeni metonimik anlamlar da kazanmıştır:

lastik [Fr. élastique]

KT'de "kauçuktan veya goma-lastikten yapılan çekildikçe uzayan madde; ayakkabı üzerine giyilen kauçuktan galoş" anlamını taşıyan lastik kelimesi, Fransızcada "esnek; lastik, lastikten yapılmış" gibi anlamlara gelmektedir. Güncel Türkçede kelime, KT'deki anlamları korumakla birlikte bunlara ek olarak farklı kullanımlar da kazanmıştır. GTS'de lastik kelimesi "ayakkabı üzerine giyilen kauçuktan pabuç; kauçuktan yapılmış ayakkabı; kauçuktan yazı silgisi; taşıtların jantlarına yerleştirilen elastiki tekerlek bandaj1; esnek, ince kauçuk veya kauçuklu şerit; bir tür esnek örgü; korse; uzun konçlu çorabın düşmesini önlemek için üst kısmına gelecek biçimde bacağa geçirilen esnek şerit; kauçuktan yapılmış" gibi çeşitli anlamlar taşır. Kelime KT'den farklı bir şekilde lastikten yapılmış "silgi, ayakkabı, tekerlek bandajı, esnek şerit, saç tokası" gibi farklı eşyaları karşılayarak hammadde-eşya ilişkisiyle metonimik anlam kazanmıştır. Bununla birlikte lastik kelimesi, Türkçeye ödünçlenirken kelime türü de değiştirilmiştir. Fransızca élastique sıfattır ve esnek yapıda olan maddeleri belirtmek için kullanılır. Lastik kelimesi, Türkçede KT'den günümüze isim göreviyle kullanım alanı bulmuş; ancak aynı Fransızca kelimeden farklı bir fonolojiyle ödünçlenen elastik kelimesi "esnek" anlamıyla sıfat olarak kaynak dildekine uygun bir şekilde yerleşmiştir.

paspas [Fr. paillase/paillasse]

"Ayakları silmek için kapı önüne konulan tüylü hasır" anlamıyla KT'de yer alan paspas ${ }^{19}$ kelimesi, aynı şekilde GTS'de de bulunmaktadır. Bu anlama ek olarak kelime, güncel Türkçede "yer silmekte kullanılan, özel olarak yapılmış bir sopa ve onun ucuna geçirilmiş bezden oluşan temizlik aracı" şeklinde farklı bir anlam da kazanmıştır. Metonimi yoluyla yeni bir kavramı karşılayan paspas kelimesinde, eşya-yer veya eşya-işlev ilişkisi etkili olmuştur.

pike [Fr. piqué]

KT'de bulunan pike kelimesi Fransızcadaki anlamına uygun bir şekilde "kabartma benekli ve kalınca bez" şeklinde tanımlanmaktadır. Kelime aynı anlamla güncel Türkçede kullanılmakla birlikte, metonimik olarak "bu tür kumaştan yapılan yatak örtüsü" anlamı kazanmıştır. Metonimi yoluyla oluşan bu anlam ilişkisinde hammadde-madde ilişkisi etkili olmuştur.

19 Paspas kelimesinin Fransızca kaynağıyla ilgili iki farklı görüş bulunmaktadır. Osmanlı dönemi sözlüklerinde kelime "ot minder; şilte" anlamına gelen Fransızca paillasse kelimesine dayandırılır. Daha sonraki çalışmalarda ise kelimenin Fransızca passe passe "geç geç" anlamındaki ifadeden ödünçlendiği üzerinde durulmaktadır (bk. Uysal 2014: 102-103). Hangi kökten gelirse gelsin kelimenin Türkçede, orijinal dilde bulunmayan özgün bir anlam taşıdığı görülmektedir.

Adres Address

RumeliDE Dil ve Edebiyat Araştrmaları Dergisi $\quad$ RumeliDE Journal of Language and Literature Studies Osmanağa Mahallesi, Mürver Çiçeği Sokak, No:14/8 Osmanağa Mahallesi, Mürver Çiçeği Sokak, No:14/8 Kadıköy - İSTANBUL / TÜRKIYE 34714 Kadıköy - ISTANBUL / TURKEY 34714 e-posta: editor@rumelide.com e-mail: editor@rumelide.com tel: +90 505 7958124, +90 216773 o 616 phone: +90 505 7958124, +90 216773 o 616 


\section{silindir [Fr. cylindre]}

Fransızcadan ödünçlenen silindir kelimesi "buhar içindeki pistona kuvvetli bir itişin sağlandığı iç tarafı oyuk iki tarafı kapalı silindir" olarak açıklanmaktadır. Kelimenin Fransızcada temel anlamı "sabit bir düz çizgiye paralel hareket eden ve sabit bir düzlemsel kapalı eğriyle kesişen düz bir çizgi ile izlenen yüzey" olarak tanımlanabilecek geometrik cisimdir. Geometrik bir terim olan silindir, Türkçede Cumhuriyet dönemine kadar Arapça üstüvâne kelimesiyle karşılandığı için KT'de silindir kelimesi, temel anlamıyla değil, "silindir şekilli piston odası" kavramını karşılayacak bir şekilde dar anlamıyla ödünçlenmiştir. Cumhuriyet döneminden sonra Arapça üstüvâne yerine Fransızca silindir kelimesi kullanım yaygınlığı kazanmıştır. Bu nedenle GTS'de kelimenin ilk tanımı, geometrik cisimdir. Bununla birlikte silindir kelimesi, güncel Türkçede KT'dekinden farklı anlamlar da ifade eder: "Metalleri inceltme, kumaşları parlatma, kağıt üzerine baskı yapma vb. işler için sanayide kullanılan merdane, silindir makinesi; motorlu taşıtların motorunda pistona güçlü bir itiş sağlamak için gaz karışımının yandığı veya patladığı yer; yol yapımında toprağı sıkıştırarak düzleştirmek için kullanılan genellikle motorlu araç; silindir şapka". Silindir kelimesinin gösterdiği söz konusu anlamların tamamı, metonimik olarak şekil-eşya ilişkisiyle kurulan anlamlardır. Başka bir deyişle, silindir şekilli eşyalar, sahip oldukları şekil özellikleri ile tanımlanmıştır.

\section{tuvalet [Fr. toilette]}

Fransızcadan ödünçlenen tuvalet kelimesi, KT"de "yüz yıkayı taranma ve giyinme işleri"ni karşılayan bir anlama gelir. Güncel Türkçede KT'de belirtilen anlam korunmakla birlikte, kelimenin temel ve yaygın anlamı "insanın dışkısıyla idrarını boşalttığı yer, hela"dır. Kelimenin "yıkanma, giyinme, süslenme, taranma" anlamından "hela" anlamına doğru anlam değişmesine uğramasında metonimik anlam ilişkisi etkili olmuştur. "Taranma, yıkanma, süslenme eşyalarının bulunduğu yer veya bu işlemlerin yapıldığı yer"den "dışkı boşaltımının yapıldı̆̆ı yer"e hareket-yer ilişkisiyle veya "yıkanma, temizlenme"den "dışkı boşaltımına" doğru anlam aktarımıyla metonimik anlam doğmuştur. "Yıkanma, taranma, süslenme" gibi daha olumlu anlamdan olumsuz çağrışımı bulunan "hela"ya doğru anlam gelişimini anlam kötüleşmesi olarak ele almak da mümkündür. Ancak kelimenin geçirdiği anlam değişiminin temelinde, anlam kötüleşmesi değil, açıkça söylenmek istenmeyen veya söylenmesi tabu kabul edilen kelimeleri farklı kavramlarla karşılama eğilimi olan örtmece (İng. euphemism) bulunmaktadır.

tül [Fr. tulle]

KT'de "çok ince ve seyrek bez, tülbent" şeklinde anlamlandırlan tül kelimesi, güncel Türkçede de belirtilen anlamı korumakla birlikte, buna ek olarak metonimik bir anlam ilişkisiyle (hammaddemadde) "bu tür dokumadan yapılmış olan ürün"leri karşılar bir nitelik kazanmıştır. Bununla birlikte tül kelimesinin GTS'de yer almayan bir kullanımı daha vardır. Özellikle perde yapımında yaygın bir şekilde kullanılan tül, "tül perde" şeklindeki ifadenin kısaltılmasıyla birlikte sadece tül olarak "tül perde"yi belirten bir anlam da göstermektedir.

KT'de yer alan bazı Fransızca alıntı kelimelerin ise gösterdiği anlam, güncel Türkçede metonimik olarak tamamen değişmiştir:

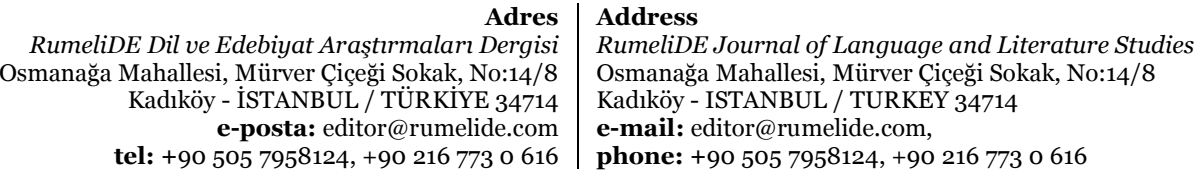


obüs [Fr. obus]

Askerî bir terim olarak Fransızcadan ödünçlenen obüs kelimesi, KT'de "küçük humbara, tane" anlamını taşımaktadır. Aynı kelime GTS'de metonimik bir anlam değişimine uğramış, alet-parça ilişkisiyle "havan topu mermisi" anlamından uzaklaşarak "yüksek ve alçaktan mermi atabilen kısa namlulu top" anlamını kazanmıştır.

\subsubsection{Sinekdoka}

Sinekdoka (İng. synecdoche), parça-bütün ilişkisine dayanan metonimi türüdür (Cruse 2006: 108; Campell\&Mixco 2007: 199). Başka bir deyişle, parça bütüne veya bütün parçaya atıfta bulunmak için kullanılır. KT'den güncel Türkçeye diğer türlere göre çok daha az sayıda sinekdoka yoluyla oluşmuş anlam değişmesi tespit edilmiştir:

\section{apartman [Fr. appartement]}

Fransızca apartman kelimesi KT'de "birkaç odadan oluşan ve bir ailenin yaşamasına elverişli daire" anlamına gelmektedir. Güncel Türkçede de yaygın bir şekilde kullanılan apartman kelimesi KT'den farklı olarak "birkaç katlı ve her katında bir veya birkaç daire bulunan yapı"yı karşılar. Kelime Fransızcada KT'deki anlamıyla "ayrı oda veya odalardan oluşan daire"yi karşılar. Buna göre güncel Türkçede kelime, hem KT'deki hem de orijinal dildeki anlamından farklılaşmıştır. Apartman kelimesinin anlamı, parça-bütün ilişkisiyle değişmiş; parça (daire, müstakil yapı) yerine bütünü (dairelerin oluşturduğu yapı, müstakil paylara bölünmüş bina) karşılamaya başlamıştır. Güncel Türkçede dairelerin oluşturduğu yapının tamamı apartman kelimesiyle ifade edilirken apartmanın parçalarını oluşturan yapılar apartman dairesi veya kısaltılmış bir şekilde sadece daire kelimeleriyle ifade edilir. Bununla birlikte aynı kökten (Latince) gelen apart kelimesi, apart veya apart otel şeklinde "müstakil olarak bölünmüş oda veya odalar"ı karşılar şekilde Türkçede kullanılmaktadır.

\section{Galatlardan kaynaklanan anlam değişmeleri}

Galat, genellikle başka dillerden ödünçlenen kelime ve unsurların fonolojik ve anlamsal açıdan kaynak dildekinden farklı veya yanlış bir şekilde kullanılarak alıcı dilde yaygınlık kazanmasıdır (Kültüral 2008: 1). Fransızca alıntı kelimelerin orijinal kullanımlarından farklı ve yanlış sayılabilecek bir anlama işaret etmeleri sonucu oluşan galatlar, oluşumları açısından yukarıda ele aldığımız anlam olayları kaynaklı anlam değişmelerinden farklıdır. Bazı Fransızca alıntı kelimeler, KT'de kaynak dilden farklı ve yanlış bir kullanım özelliği gösterirken güncel Türkçede bu hata düzeltilmiştir:

\section{trampete (GTS trompet) [Fr. trompette]}

Fransızcadan ödünçlenen ve KT'de "çift çomakla çalınan küçük davul" anlamı verilen trampete kelimesi, kaynak dilde "boru; borazan" anlamlarına gelmektedir. Başka bir deyişle, Fransızca trompette "borazan" kelimesi, galat sonucu "davul" kavramını karşılayan bir kelime olarak ödünçlenmiştir. Güncel Türkçede trompet şeklinde fonolojik değişime uğrayan kelime, kaynak dildeki anlamına uygun bir şekilde "nefesli çalgı"yı karşılar. Bununla birlikte güncel Türkçede "iki değnek ile çalınan küçük davul" kavramı için İngilizce drumbeat kelimesi trampet şeklinde ödünçlenmiştir. Bu galatın doğmasında, Batı dillerinde "davul" ve "borazan" müzik aletlerini karşılayan kelimelerin yakın fonolojik özelliklere sahip olması etkili olmuştur.

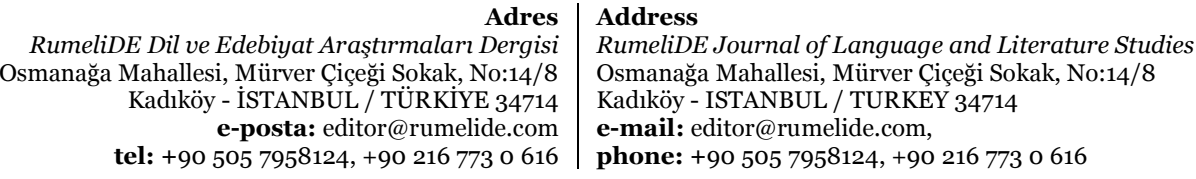


KT'de kaynak dil Fransızcadakine uygun kullanım ve anlam özelliğini gösteren bazı kelimeler ise güncel Türkçede farklı ve yanlış anlamları ifade eder hâle gelmiştir:

forma [Fr. forme], üniforma [Fr. uniforme]

Aynı kökten gelen üniforma ve forma kelimeleri, KT'de Fransızcadan ödünçlenmiş kelimeler olarak çeşitli kullanım özellikleriyle tanımlanır. Bu kelimelerden üniforma, KT'de "resmi elbise, alay elbisesi" şeklinde; forma ise matbaacılık terimi olarak "bir arada basılacak sayfa kalıplarını sıkıştırmak için kullanılan demir çerçeve; bir arada basılacak sayfaların toplamı" ve denizcilikte ise "inşa olunan gemilerin etrafına vurulan desteklerin başlarının altına konulan kuşak; bir arada hareket eden donanmanın oluşturduğu teşkilat" anlamlarını taşır. Aynı kelimelerin GTS'deki karşılıkları ise üniforma için "aynı işi yapanların giydikleri, tüzükle belirtilmiş, bir örnek giysi; silahlı kuvvetlerin resmî giysisi"; forma için "biçim, şekil; öğrencilerin sporcuların, bazı mesleklerde çalışanların giydikleri, bağlı bulundukları okul, spor kulübü veya meslekleri belirten tek tip giysi; tek kağıt tabaka üzerine basılan on altı sayfalık kırılmış kitap parçası" şeklindedir. Verilen tanımlardan görüldüğü üzere, güncel Türkçede forma kelimesinin "tek tip giysi" anlamı, üniforma kelimesinin anlamıyla örtüssen bir kullanım özelliğine sahiptir. Kaynak dil olan Fransızcada forme kelimesinin temel anlamı "görünüş, şekil, biçim"dir ve kelime bu temel anlamdan gelişen bir anlam çeşitliliği göstermektedir. Uniforme kelimesi ise uni- "tek" ile biraz yukarıda açıkladığımız forme kelimesinin birleşiminden oluşmuş "tek şekil veya görünüşe sahip olma" genel anlamından 18. yüzyılda "bir grup tarafından giyilen ayırt edici tek tip giysi" özel anlamını karşılar hâle gelmiştir. ${ }^{20}$ Üniforma kelimesi, KT'de ve GTS'de kaynak dildeki anlamına uygun bir kullanıma sahip olmakla birlikte forma kelimesi, bir galat olarak üniforma kelimesinden kısaltılarak söz konusu kelimenin karşllğ̆ olarak kullanım yaygınlığı kazanmıştır. Bununla birlikte, forma genel olarak "tek tip kıyafet" türünü karşlarken üniforma kelimesi daha çok "resmi kıyafet" için kullanım alanı bulmuştur. Bu tercih ve nüansın doğmasında, üniforma kelimesinin KT'de de görüleceği üzere "resmi elbise (özellikle askerî klyafet)" olarak ödünçlenmesi ve forma kelimesinin de galat olarak "tek tip kıyafet"i karşılamasının etkili olduğu düşünülebilir.

kabine [Fr. cabinet], kabin [Fr. cabine]

KT'de "bir devletin hükümeti, vekiller heyeti" anlamıyla yer alan kabine kelimesi, güncel Türkçede de yaygın olarak aynı anlamda kullanılmakla birlikte "doktor muayenehanesi; kabin; hela" gibi çeşitli anlamlar da kazanmıştır. GTS'de kabine kelimesine verilen kabin karşılığı bir galattan doğmuştur. Fransızca cabinet, "oda; hususi oda; ofis, büro; hükümet, bakanlar kurulu; hela" gibi farklı anlamlar taşıyan bir kelimedir. Aynı kökten gelen cabine ise cabinet kelimesinden farklı olarak "küçük oda; küçük bölme; (gemide) kamara; (hamamda) küçük oda" anlamına gelir. Fransızca cabine kelimesi, kabin şeklinde; kabine kelimesinden daha sonraki bir dönemde Türkçeye ödünçlenmiştir. Kabin kelimesi, Türkçede aslına uygun bir şekilde "küçük, özel bölme; (gemi, uçakta) küçük bölme; plajda soyunma yeri" anlamlarını taşır. Dolayısıyla kabine kelimesi KT'den günümüze anlam değişimine uğramış, ancak taşıdığı yeni anlamlardan birisi (kabin) galat yoluyla oluşmuştur.

\section{Sonuc}

Kamus-ı Türkî kapsamında 19. yüzyıldan günümüze Fransızca alıntı kelimelerdeki anlam değişmeleriyle ilgili elde ettiğimiz verilerden ulaştığımız sonuçları şu şekilde özetlemek mümkündür:

${ }_{20} \quad$ https://www.etymonline.com/search?q=\%C $3 \%$ BCniforme Adres $\mid$ Address

RumeliDE Dil ve Edebiyat Araştırmaları Dergisi $\quad$ RumeliDE Journal of Language and Literature Studies Osmanağa Mahallesi, Mürver Çiçeği Sokak, No:14/8 Osmană̆a Mahallesi, Mürver Çiçeği Sokak, No:14/8 Kadıköy - ISTANBUL / TÜRKIYE 34714 Kadıköy - ISTANBUL / TURKEY 34714 e-posta: editor@rumelide.com e-mail: editor@rumelide.com, tel: +90 505 7958124, +90 216773 o 616 phone: +90 505 7958124, +90 2167730616 
KT'de tespit edilen 241 Fransızca alıntı kelimeden 9'u (akonit "kurt boğan olarak bilinen bir bitki", enfluenze "şiddetli nezle", bokal "bir tür şişe", retret "süresi uzatılmış yeni poliçe", sale "odaların arasında açık yer; geniş ve umumi oda", sultat "bir tür tüfek", gron "bir tür kumaş", koper "bir tür balık", lak "bahçe havuzu") GTS'de bulunmamaktadır. Burada özellikle belirtmemiz gerekir ki, anlam değişmesi türleri arasındaki sınırları net bir şekilde tespit etmek mümkün değildir. Örneğin bir kelimenin metaforik bir anlam kazanması, aynı zamanda kelimenin anlam genişlemesi göstermesine veya metonimik bir anlam değişmesi, beraberinde anlam daralmasına da neden olabilmektedir. Anlam değişmeleri türlerinin birbiriyle ilişkili yapısıyla birlikte kelimelerin çok anlamlılığı da bir kelimenin anlamında meydana gelen değişimin tam olarak belirlenmesine engel olur. Çok anlamlı bir kelimenin işaret ettiği her anlam, farklı anlam değişmesi türleriyle oluşabilir. Bu açıdan KT'den güncel Türkçeye anlam değişmeleri türlerinin ayrı ayrı oranlarını belirlemek sağlıklı sonuçlar doğurmayacaktır. Bu noktada çıkarılabilecek genel bir sonuç, KT ve GTS'de ortaklaşan 232 kelimeden 105'inin (yaklaşık \%45'i) güncel Türkçede anlam değiş̧mesine uğramış olmasıdır. KT'deki 241 Fransızca alıntı kelimeden 198'i (yaklaşık \%82'si) tek anlamlıdır. Söz konusu 198 kelimeden 8'i GTS'de yer almaz, geriye kalan 190 tek anlamlı kelimeden 74'ü (yaklaşık \%39'u) güncel Türkçede çok anlamlı olarak kullanılmaktadır. KT'den güncel Türkçeye Fransızca alıntı kelimelerde görülen anlam değişmeleri, büyük oranda kaynak dildeki anlamlara paralellik gösterir. 19. yüzyıldan sonra da Türkçe-Fransızca dil temasının devam ettiğini gösteren bu durum, Fransızca kelimeler daha iyi tanındıkça ve yeni kavramları karşılama ihtiyacı doğunca daha önce ödünçlenmiş kelimelerin diğer anlamlarının da dile uyarlanmasından kaynaklanmaktadır. Bununla birlikte, Fransızca alıntı kelimelerin kaynak dilde bulunmayan anlam ve kullanımlarının Türkçede ortaya çıkması da söz konusudur. Özgün anlamlı alıntı kelimeler olarak adlandırabileceğimiz bu tür kelimelerin Türkçeye uyarlanma süreçlerinin tamamlandığını düşünebiliriz.

\section{Kisaltmalar}

$\begin{array}{ll}\text { bk. } & \text { bakınız } \\ \text { Fr. } & \text { Fransızca } \\ \text { GTS } & \text { Güncel Türkçe Sözlük } \\ \text { İng. } & \text { İngilizce } \\ \text { KT } & \text { Kamus-ı Türkî }\end{array}$

\section{Yazılı kaynaklar}

\section{Kaynakça}

Adelaar, K. A. (1994). Malay and Javanese loanwords in Malagasy, Tagalog and Siraya (Formasa). Bijdragen tot de Taal-, Land-en Volkenkunde, 15o(1), 50-65.

Anam, M. K. ve Nirmala, D. (2019). Semantic changes of English loanwords in Radar Kediri daily newpaper headlines. Parole: Journal of Linguistics and Education, 9(2), 80-89.

Apenteng, M. A. ve Amfo, N. A. (2014). The form and function of English loanwords in Akan. Nordic Journal of African Studies, 23(4), 219-240.

Bader, Y. (1990). Semantic change in Arabic loanwords from English and French. Abhath AlYarmouk: Literature and Linguitics Series, 8(2), 33-48.

Barber, C. L. (1964). Linguistic change in present-day English. Edinburgh: Oliver\&Boyd.

Bator, M. (2010). Obsolete Scandinavian loanwords in English. Frankfurt: Peter Lang.

Bellows, J. ve Bellows, W. (1919). Dictionary of French and English, English and French (3. bs.). London: Longmans, Green.

\begin{tabular}{r|l} 
Adres & Address \\
RumeliDE Dil ve Edebiyat Araşttrmalar Dergisi & RumeliDE Journal of Language and Literature Studies \\
Osmanağa Mahallesi, Mürver Çiçeği Sokak, No:14/8 & Osmanağa Mahallesi, Mürver Çiçeği Sokak, No:14/8 \\
Kadıköy - İSTANBUL / TÜRKIYE 34714 & Kadıköy - ISTANBUL / TURKEY 34714 \\
e-posta: editor@rumelide.com & e-mail: editor@rumelide.com, \\
phone: +90 505 7958124, +90 2167730616
\end{tabular}


Blank, A. (1999). Why do new meanings occur? A cognitive typology of the motivations for lexical semantic change. A. Blank ve P. Koch (eds.), Historical semantics and cognition. Berlin, New York: Mouton de Gruyter, 61-89.

Bloomfield, L. (1933). Language. London: George Allen\&Unwin Ltd.

Breiter, M. (1997). What is the difference between "shashlyk" and "barbecue"? Perspectives: Studies in Translatology, 5(1), 85-100.

Bussmann, H. (1999). Routledge dictionary of language and linguistics. London, New York: Routledge.

Campbell, L. ve Mixco, M. J. (2007). A glossary of historical linguistics. Edinburgh: Edinburgh University Press.

Cruse, A. (2006). A glossary of semantics and pragmatics. Edinburgh: Edinburgh University Press.

Crystal, D. (2008). A dictionary of linguistics and phonetics (6.bs.). USA\&UK: Blackwell Publishing.

Çiçek, A. (2009). Sözlük bilimi açısından Kâmûs-ı Türkî üzerine bir inceleme. Erzincan Eğitim Fakültesi Dergisi, 11(2), 183-193.

Danesi, M. ve Rocci, A. (2009). Global linguistics: An introduction. Berlin: Mouton de Gruyter.

Demiray, K. (1981). Sözlükçülüğümüzde önemli bir aşama ve Kamûs-ı Türkî. Türk Dili Dergisi, XLIII, 24-26.

Durmuş, O. (2004). Alıntı kelimeler bakımından Türkçe sözlük. Atatürk Üniversitesi Türkiyat Araştırmaları Enstitüsü Dergisi, 26, 1-21.

Görlach, M. (2003). English words abroad. Amsterdam: John Benjamins Publishing.

Hall-Lew, L. A. (2002). English loanwords in Mandarin Chinese. BA Honors Thesis, University of Arizona, Tuscon.

Haspelmath, M. (2009). Lexical borrowing: Concepts and issues. M. Haspelmath ve U. Tadmor (Ed.), Loanwords in the World's Languages. Berlin: De Gruyter Mouton, 35-54.

Haugen, E. (1950). The analysis of Llnguistic borrowing. Language, 26, 210-231.

Herman, J. ve de Vries, Jr. (2008). Dutch: Is it threatened by English? J. Rosenhouse ve R. Kowner (eds.), Globally speaking: motives for adopting English vocabulary in other languages. Clevedon, UK: Multilingual Matters.

Hock, H. H. (1980). Introduction to historical linguistics: A handbook for graduate students in linguistics. Urbana: University of Illinois Typescript.

Hoffmann, Z. (2011). Ways of the world's words: Language contact in the age of globalizaton. Bern: Peter Lang.

Johanson, L., Csató, É. Á. ve Karakoç, B. (2020). Turkic language contacts (2. bs.). R. Hickey (ed.), The Handbook of language contact. USA\&UK: Wiley Blackwell, 551-570.

Kay, G. (1995). English loanwords in Japanese. World Englishes, 14(1), 67-76.

Kittay, E. F., Lehrer, A. (1992). Introduction. A. Lehrer ve E. F. Kittay (Ed.), Frames, fields, and contrasts: New essays in semantic and lexical organization. Hillsdale, NJ: Lawrence Erlbaum Associates, Publishers, 1-8.

Kowner, R. ve Daliot-Bul, M. (2008). Japanese: The Dialectic relationships between "westerness" and "japaneseness" as reflected in English loanwords. J. Rosenhouse, R. Kowner (ed.), Globally speaking: motives for adopting English vocabulary in other languages. Clevedon, UK: Multilingual Matters.

Kültüral, Z. (2008). Galatât sözlükleri. İstanbul: Simurg.

Magrelo, I. (2011). Türkçede Batı kökenli yabancı sözcükler. Uluslararası Sosyal ve Ekonomik Bilimler Dergisi, 1(1), 7-10.

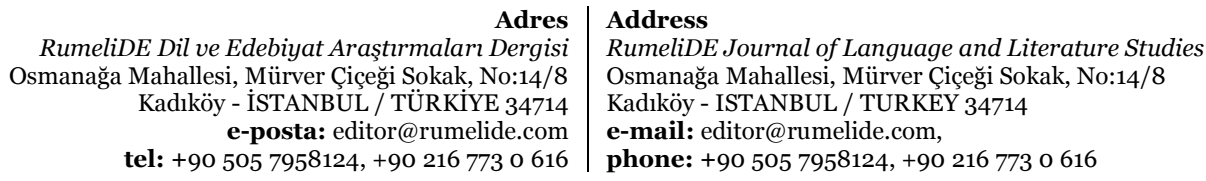


Murphy, M. L. ve Koskela, A. (2010). Key terms in semantics. London,New York: Continuum International Publishing Group.

Myers-Scotton, C. (2002). Language contact: Bilingual encounters and grammatical outcomes. Oxford: Oxford University Press.

Pyles, T. ve Algeo, J. (1982). The Origins and development of the English language. New York: Harcout Brace Jovanovich.

Rebuck, M. (2002). The Function of English loanwords in Japanese. Journal of Language Culture and Communication, 4(1), 53-64.

Saraç, T. (1985). Büyük Fransızca-Türkçe sözlük. İstanbul: Adam.

Stern, G. (1931). Meaning and change of meaning with special reference to the English language. Bloomington: Indiana University Press.

Şemseddin Sami (2017). Resimli Kâmûs-ı Fransevî. Haz. Şerif Eskin, Ankara: Türkiye Bilimler Akademisi.

Şemseddin Sami (2019). Kamus-ı Türkî (3. bs.), Haz. Paşa Yavuzarslan, Ankara: Türk Dil Kurumu.

Trask, R. L. (1994). Language change. London\&New York: Routledge.

Ullmann, S. (1967). Semantics: An Introduction to the science of meaning. Oxford: Blackwell.

Uysal, S. S. (2014). Türkçe'de yaratılan "Fransızca" sözcükler ve Türkçe'de anlamları değiştirilen Fransızca sözcükler. İstanbul: Yapı Kredi.

Weinreich, U. (1963). Languages in contact. Paris, New York: Mouton Publishers.

Yavuzarslan, P. (2004). Türk sözlükçülük geleneği açısından Osmanlı dönemi sözlükleri ve Şemseddin Sâmî'nin Kâmûs-ı Türkî'si. Ankara Üniversitesi Dil ve Tarih-Coğrafya Fakültesi Dergisi, 44(2), 185-202.

\section{Elektronik kaynaklar}

Güncel Türkçe Sözlük (Türkçe Sözlük'ün 11. baskısının gözden geçirilip güncellenmiş olarak genel ağdan sunulan sürümü.) https://sozluk.gov.tr/ (Erişim tarihi: 29.10.2020)

İngilizce Etimolojik Sözlük, https://www.etymonline.com/ (Erişim tarihi: 29.10.2020)

Merriam-Webster's Collegiate Dictionary, Eleventh Edition, https://www.merriam-webster.com/ (Erişim tarihi: 29.10.2020) 